Prepared in cooperation with the Southwest Florida Water Management District

\title{
A Geochemical Mass-Balance Method for Base-Flow Separation, Upper Hillsborough River Watershed, West-Central Florida, 2003-2005 and 2009
}

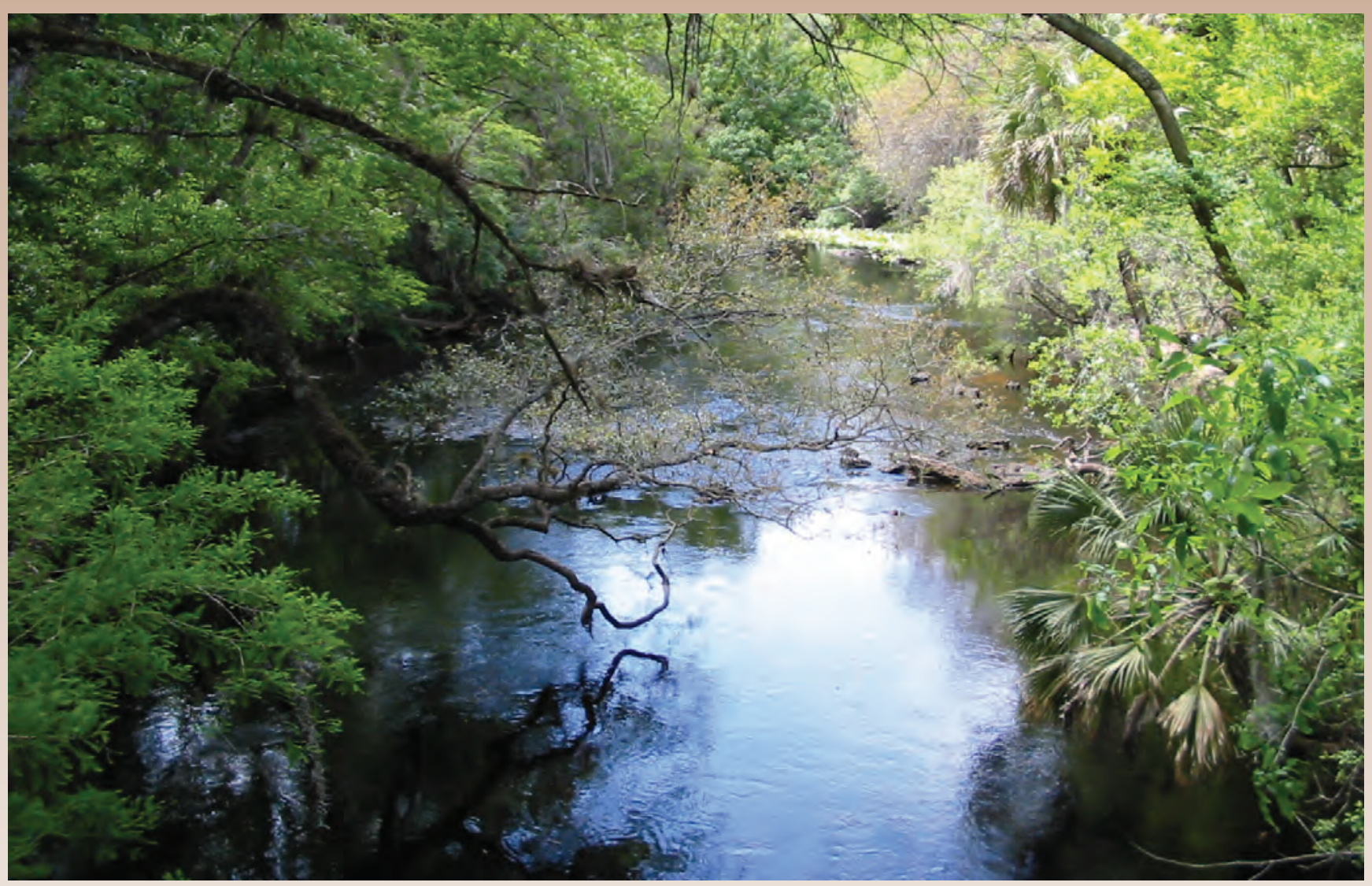

Scientific Investigations Report 2010-5092 
Photo Credits Cover and pages i-viii, and 9 - Dan Duerr, U.S. Geological Survey (retired) 


\section{A Geochemical Mass-Balance Method for Base-Flow Separation, Upper Hillsborough River Watershed, West-Central Florida, 2003-2005 and 2009}

By G.R. Kish, C.E. Stringer, M.T. Stewart, M.C. Rains, and A.E. Torres

Prepared in cooperation with the Southwest Florida Water Management District

Scientific Investigations Report 2010-5092 


\title{
U.S. Department of the Interior KEN SALAZAR, Secretary
}

\author{
U.S. Geological Survey \\ Marcia K. McNutt, Director
}

\section{U.S. Geological Survey, Reston, Virginia: 2010}

For more information on the USGS - the Federal source for science about the Earth, its natural and living resources, natural hazards, and the environment, visit http://www.usgs.gov or call 1-888-ASK-USGS

For an overview of USGS information products, including maps, imagery, and publications, visit http://www.usgs.gov/pubprod

To order this and other USGS information products, visit http://store.usgs.gov

Any use of trade, product, or firm names is for descriptive purposes only and does not imply endorsement by the U.S. Government.

Although this report is in the public domain, permission must be secured from the individual copyright owners to reproduce any copyrighted materials contained within this report.

Suggested citation:

Kish, G.R., Stringer, C.E., Stewart, M.T., Rains, M.C., and Torres, A.E., 2010, A Geochemical Mass-Balance Method for Base-Flow Separation, Upper Hillsborough River Watershed, West-Central Florida, 2003-2005 and 2009:

U.S. Geological Survey Scientific Investigations Report 2010-5092, 33 p.. 


\section{Acknowledgments}

The authors gratefully acknowledge the cooperation and assistance of Michael Hancock from the Southwest Florida Water Management District for suggestions and comments on early drafts of the report and Patrick Potts, Park Services Specialist, Hillsborough River State Park, who provided logistical support during data-collection activities.

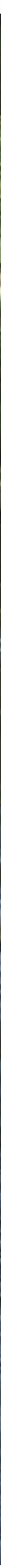




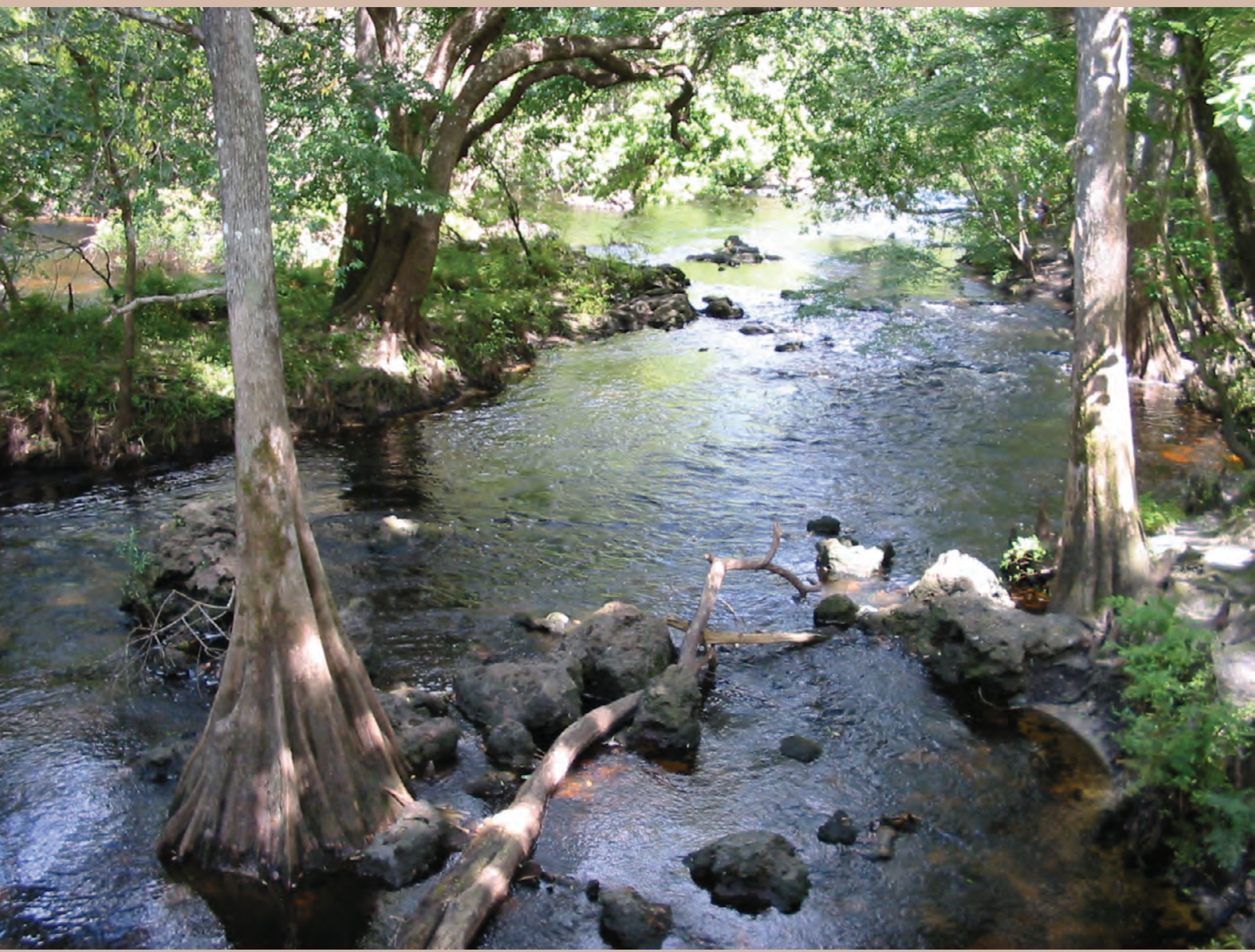




\section{Contents}

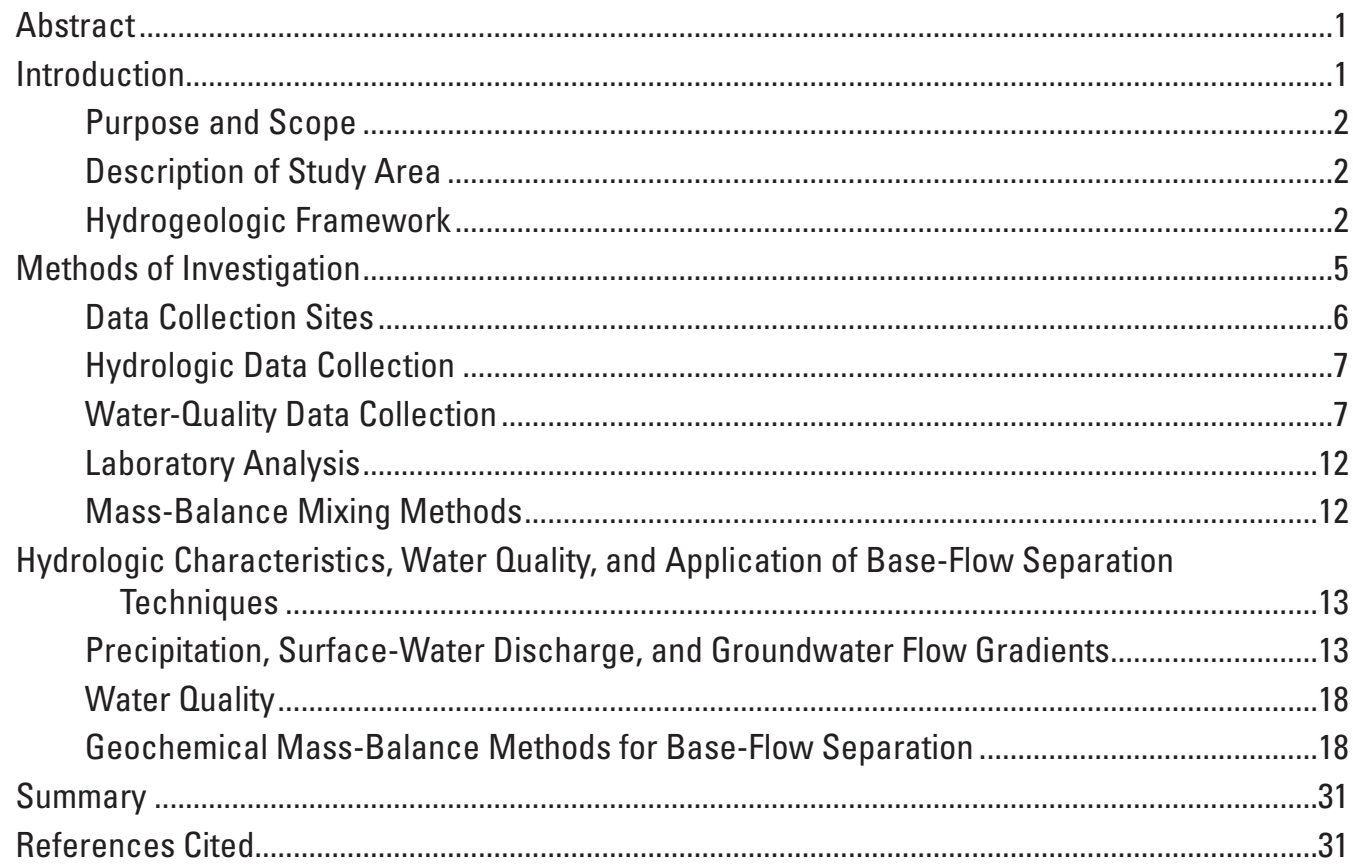

\section{Figures}

1. Map showing study area, showing data collection sites in the upper Hillsborough River watershed and boundary of the Hillsborough River watershed................................

2. Generalized hydrostratigraphy of the study area...........................................................

3. Photograph showing limestone outcrop of the Tampa Member of the Arcadia Formation in the Hillsborough River at Hillsborough River State Park. ............................

4. Aerial photograph showing data collection locations at the SR39 site ............................

5. Aerial photograph showing data collection locations at the HRSP site ...........................

6. Hydrogeologic section $\left(A-A^{\prime}\right)$ and groundwater flow during the wet season, (July 12, 2003) and dry season (February 11, 2005) at the SR39 site...

7. Hydrogeologic section $\left(B-B^{\prime}\right)$ and groundwater flow during the wet season, (July 12, 2003) and dry season (February 11, 2005) at the HRSP site

8-14. Graphs showing -

8. Daily average discharge and maximum and minimum specific conductance during a storm event at station 2303000, Hillsborough River near Zephyrhills, Florida ...

9. Daily precipitation at the SR39 and HRSP study areas from February 1, 2003 , to June 1,2005

10. Weekly throughfall and total precipitation at the SR39 and HRSP study areas from February 1, 2003, to March 30, 2005

11. Hydrographs of mean daily discharge for the SR39 and HRSP sites from February 1, 2003, to April 30, 2005 
12. Duration curves of mean daily discharge for the SR39 site for calendar years 2003-2005, and the HRSP site for calendar years 2003-2009........................16

13. Weekly groundwater levels and river stage at the SR39 site ................................17

14. Weekly groundwater levels and river stage at the HRSP site .................................17

15. Stiff diagrams of geochemical analyses for precipitation, surface water, and groundwater at the SR39 site.

16. Stiff diagrams of geochemical analyses for precipitation, surface water, and groundwater at the HRSP site

17-20. Graphs showing-

17. Selected median constituent concentrations in water at the SR39 and HRSP sites for dry and wet seasons, and for groundwater samples from Upper Floridan aquifer wells, 2003-2005 for calcium, dissolved organic matter, magnesium, and strontium.

18. Strontium concentrations in surface water and the Upper Floridan aquifer at the SR39 site on March 19, 2003

19. Relation between ${ }^{87} \mathrm{Sr} /{ }^{86} \mathrm{Sr}$ ratio and strontium concentrations in surface water and the Upper Floridan aquifer at the SR39 site on March 19, 2003

20. Relation between delta hydrogen-2 and oxygen-18 isotope concentrations in surface water at the SR39 site and HRSP site compared with local meteoric water for Florida.

21-30. Graphs showing observed storm hydrograph and discharges estimated by-

21. Geochemical mass balance for selected major ions in SR39 surface water, September 2003 storm

22. Geochemical mass balance for selected major ions in SR39 surface water, March 2004 storm

23. Conductivity mass balance in SR39 surface water, August to November 2004......26

24. Geochemical mass balance for selected major ions in SR39 surface water, January 2005 storm

25. Geochemical mass balance for selected major ions in SR39 surface water, February/March 2005 storm.

26. Conductivity mass balance in HRSP surface water, July 2004 ..............................28

27. Conductivity mass balance in HRSP surface water, September to November 2004.

28. Geochemical mass balance for selected major ions in HRSP surface water, January 2005 storm

29. Geochemical mass balance for selected major ions in HRSP surface water, February/March 2005 storm.

30. Conductivity mass balance in HRSP surface water, August and September 2009. 


\section{Tables}

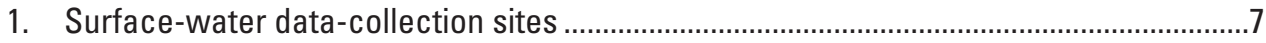

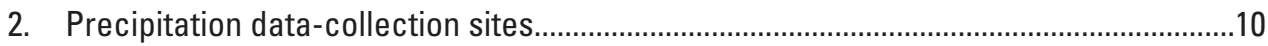

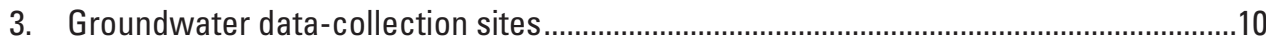

4. Annual, wet season, and dry season precipitation in the upper Hillsborough River watershed for the study period and from 1976 to 2005..................................................13

5. Summary of surface-water and groundwater quality for the Hillsborough River sites, 2003-2005

6. Pre-event and runoff end member values used in the geochemical mass balance method.

7. Model input (measured) and model results (predicted) for the sampling point at the highest discharge using the geochemical mass balance method for the SR39 site during the low intensity storm event, September 25-28, 2003.

8. Percentage of peak and average discharge attributed to base flow determined by conductivity or geochemical mass balance methods for selected constituents and storm events

\section{Conversion Factors, Datums, Abbreviations, and Acronyms}

\begin{tabular}{|c|c|c|}
\hline Multiply & By & To obtain \\
\hline \multicolumn{3}{|c|}{ Length } \\
\hline inch (in.) & 2.54 & centimeter $(\mathrm{cm})$ \\
\hline foot (ft) & 0.3048 & $\operatorname{meter}(\mathrm{m})$ \\
\hline mile (mi) & 1.609 & kilometer (km) \\
\hline \multicolumn{3}{|c|}{ Area } \\
\hline square mile $\left(\mathrm{mi}^{2}\right)$ & 2.590 & square kilometer $\left(\mathrm{km}^{2}\right)$ \\
\hline \multicolumn{3}{|c|}{ Flow rate } \\
\hline cubic foot per second $\left(\mathrm{ft}^{3} / \mathrm{s}\right)$ & 0.02832 & cubic meter per second $\left(\mathrm{m}^{3} / \mathrm{s}\right)$ \\
\hline inches per year (in/yr) & 2.54 & centimeters per year $(\mathrm{cm} / \mathrm{yr})$ \\
\hline
\end{tabular}

Temperature in degrees Celsius $\left({ }^{\circ} \mathrm{C}\right)$ may be converted to degrees Fahrenheit $\left({ }^{\circ} \mathrm{F}\right)$ as follows: ${ }^{\circ} \mathrm{F}=\left(1.8 x^{\circ} \mathrm{C}\right)+32$

Temperature in degrees Fahrenheit $\left({ }^{\circ} \mathrm{F}\right)$ may be converted to degrees Celsius $\left({ }^{\circ} \mathrm{C}\right)$ as follows: ${ }^{\circ} \mathrm{C}=\left({ }^{\circ} \mathrm{F}-32\right) / 1.8$

Vertical coordinate information is referenced to the National Geodetic Vertical Datum of 1929 (NGVD 29).

Horizontal coordinate information is referenced to the North American Datum of 1983 (NAD 83).

Altitude, as used in this report, refers to distance above the vertical datum.

Specific conductance is given in microsiemens per centimeter at 25 degrees Celsius $\left(\mu \mathrm{S} / \mathrm{cm}\right.$ at $\left.25^{\circ} \mathrm{C}\right)$.

Concentrations of chemical constituents in water are given either in milligrams per liter (mg/L) or micrograms per liter $(\mu \mathrm{g} / \mathrm{L})$. 


\section{Acronyms}

$\begin{array}{ll}\text { BFI } & \text { Base-flow index } \\ \text { CMB } & \text { Conductivity mass balance } \\ \text { DOC } & \text { Dissolved organic carbon } \\ \text { GMB } & \text { Geochemical mass balance } \\ \text { HYSEP } & \text { Hydrograph Separation } \\ \text { NWIS } & \text { National Water Information System } \\ \text { ROMP } & \text { Regional Observation and Monitor-well Program } \\ \text { SWFWMD } & \text { Southwest Florida Water Management District } \\ \text { USGS } & \text { U.S. Geological Survey } \\ \text { VSMOW } & \text { Vienna Standard Mean Ocean Water }\end{array}$

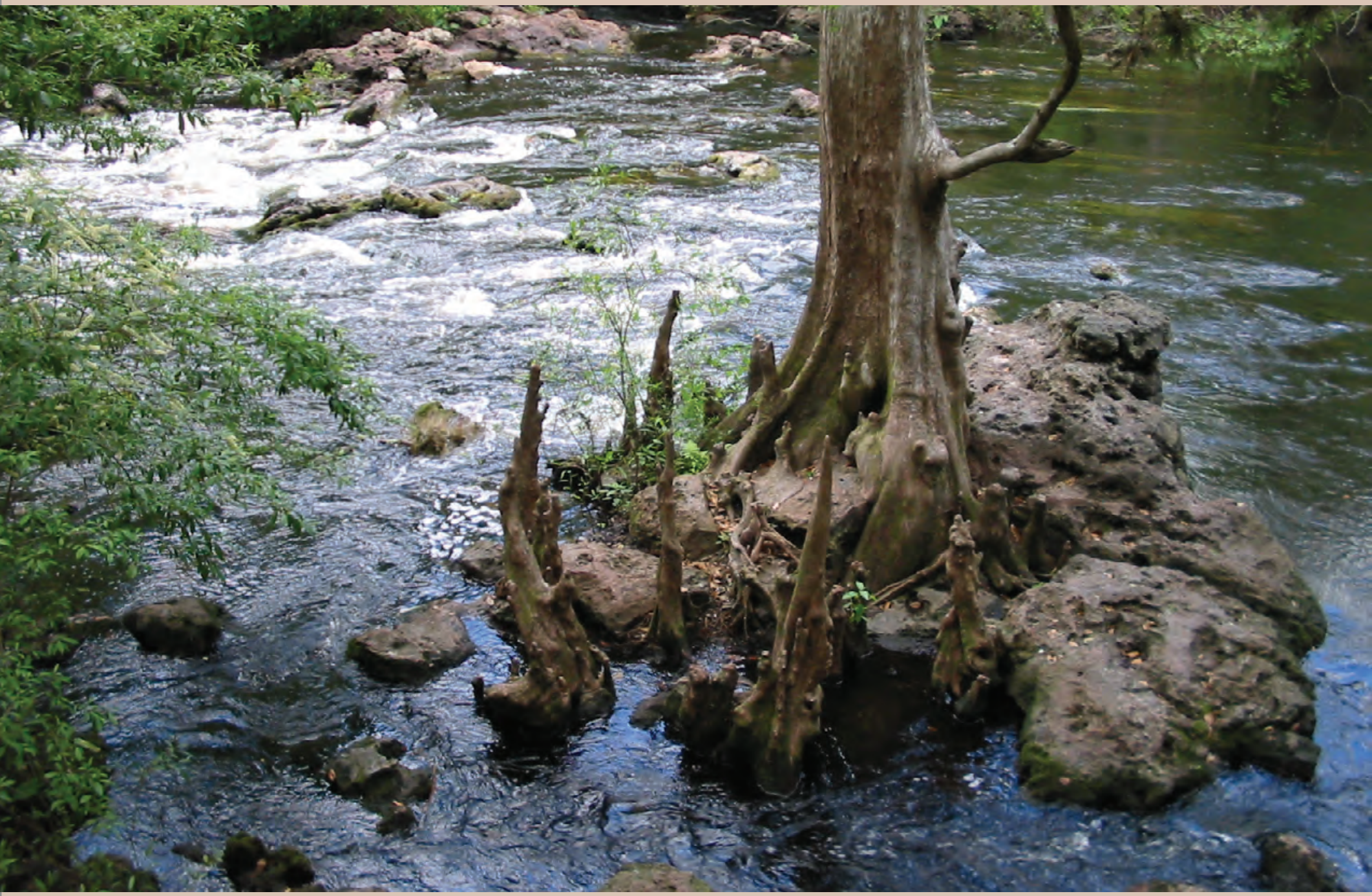




\title{
A Geochemical Mass-Balance Method for Base-Flow Separation, Upper Hillsborough River Watershed, West-Central Florida, 2003-2005 and 2009
}

\author{
By G.R. Kish', C.E. Stringer ${ }^{2}$, M.T. Stewart ${ }^{3}$, M.C. Rains ${ }^{3}$, and A.E. Torres ${ }^{1}$
}

\section{Abstract}

Geochemical mass-balance (GMB) and conductivity mass-balance (CMB) methods for hydrograph separation were used to determine the contribution of base flow to total stormflow at two sites in the upper Hillsborough River watershed in west-central Florida from 2003-2005 and at one site in 2009. The chemical and isotopic composition of streamflow and precipitation was measured during selected local and frontal low- and high-intensity storm events and compared to the geochemical and isotopic composition of groundwater. Input for the GMB method included cation, anion, and stable isotope concentrations of surface water and groundwater, whereas input for the CMB method included continuous or pointsample measurement of specific conductance.

The surface water is a calcium-bicarbonate type water, which closely resembles groundwater geochemically, indicating that much of the surface water in the upper Hillsborough River basin is derived from local groundwater discharge. This discharge into the Hillsborough River at State Road 39 and at Hillsborough River State Park becomes diluted by precipitation and runoff during the wet season, but retains the calciumbicarbonate characteristics of Upper Floridan aquifer water.

Field conditions limited the application of the GMB method to low-intensity storms but the CMB method was applied to both low-intensity and high-intensity storms. The average contribution of base flow to total discharge for all storms ranged from 31 to 100 percent, whereas the contribution of base flow to total discharge during peak discharge periods ranged from less than 10 percent to 100 percent.

Although calcium, magnesium, and silica were consistent markers of Upper Floridan aquifer chemistry, their use in calculating base flow by the GMB method was limited because the frequency of point data collected in this study was not

\footnotetext{
${ }^{1}$ U.S. Geological Survey, Tampa, FL

${ }^{2}$ Bureau of Indian Affairs, Nashville, TN

${ }^{3}$ University of South Florida, Tampa, FL
}

sufficient to capture the complete hydrograph from pre-event base-flow to post-event base-flow concentrations. In this study, pre-event water represented somewhat diluted groundwater.

Streamflow conductivity integrates the concentrations of the major ions, and the logistics of acquiring specific conductance at frequent time intervals are less complicated than data collection, sample processing, shipment, and analysis of water samples in a laboratory. The acquisition of continuous specific conductance data reduces uncertainty associated with lessfrequently collected geochemical point data.

\section{Introduction}

Streamflow in a natural channel consists of runoff and base flow, with runoff composed of overland flow and subsurface stormflow, and base flow composed of unsaturatedzone water and groundwater. Information about the base-flow component of streamflow aids in (1) understanding groundwater/surface-water interactions, (2) developing hydrologic budgets, (3) calibrating numerical models, and (4) designing runoff-routing strategies (Winter and others, 1998). During dry periods, aquatic ecosystems are maintained by groundwater discharge that sustains the flow of streams (Gebert and others, 2007).

In 1997, the Florida Legislature mandated that all of the water management districts in Florida establish minimum flows and levels for surface waters and aquifers to maintain and protect natural systems while providing water for human use (Southwest Florida Water Management District, 2007). The Florida Legislature defined "minimum flow" as the "flow for a surface watercourse at which further withdrawals would be significantly harmful to the water resources or ecology of the area and which may provide for the protection of non-consumptive uses" (Florida Administrative Code, 2000). Determining minimum flows for surface waters is difficult if the base-flow contribution to streamflow is not accurately known, as is the case in the upper Hillsborough River. 
Several methods have been developed to separate base flow from streamflow: (1) recession-curve methods, (2) recursive-digital filter methods, and (3) mass-balance methods. During 2003-2005 and 2009, the U.S. Geological Survey (USGS), in cooperation with the Southwest Florida Water Management District (SWFWMD), conducted a study to assess the surface-water and groundwater contributions to the upper Hillsborough River watershed using geochemical mass-balance (GMB) methods for base-flow separation. This study addresses the priority water-resource issues for USGS scientific activities of surface-water and groundwater interactions as related to water-resource management (U.S. Geological Survey, 1999). Understanding the interaction between groundwater and surface water is necessary in west-central Florida because of the proximity of the karstified Upper Floridan aquifer to land surface, and because it provides information that can be used to evaluate the susceptibility and sustainability of the aquifer and surface-water resources in this relatively undeveloped part of the Hillsborough River watershed (Trommer and others, 2007). Because demands for water are projected to continue to increase in the future, an understanding of how groundwater sustains streamflow during dry periods will be necessary for water-resource managers to make informed decisions about future groundwater development.

\section{Purpose and Scope}

This report describes the two approaches used to estimate the contribution of base flow to total discharge for selected storm events in two areas of the upper Hillsborough River watershed. The GMB method uses point samples of specific cations, anions, and stable isotopes, and the conductivity mass-balance (CMB) method uses both point samples of specific conductance and continuously-measured specific conductance to estimate the contribution of base flow to total discharge.

Water-quality characteristics of streamflow and precipitation were measured during selected low- and highintensity local and frontal storm events, and compared to the water-quality characteristics of pre-event surface water and groundwater. A total of 207 water-quality samples were collected, consisting of 141 surface-water samples, 55 groundwater samples, and 11 precipitation samples. Field data were collected from 2003 to 2005 and during September 2009. A mixing model was developed to estimate the percentage of pre-event (base flow) and event (runoff) water composing the hydrograph. The mixing model, which produces a direct separation of base flow and runoff, was previously used by Stewart and others (2007) to evaluate and calibrate graphical hydrograph separation techniques using a CMB method. In this report, the mixing model was applied to point samples of specific conductance, major ions (such as calcium, magnesium), stable isotopes (hydrogen and oxygen) and continuous specific conductance for selected storm events.

\section{Description of Study Area}

The study area is located in the upper Hillsborough River watershed between Dade City and Hillsborough River State Park. The upper Hillsborough River watershed drains parts of eastern Pasco and Hillsborough Counties (fig. 1). Crystal Springs, a second magnitude spring, is located next to the river about 2 mi upstream from the state park. During dry periods, Crystal Springs is a major source of water to the river. A limerock mine also is located near the river, about 2.5 mi upstream from State Road 39. Most of the river channel above the limerock mine is poorly defined and lies within a broad, heavily forested floodplain with extensive riverine wetlands and low topographic relief. The river channel below the mine to State Road 39 is moderately incised and the channel below State Road 39 to the state park is well defined (Lewelling, 2004).

With the exception of the urban and residential areas around Zephyrhills, Lakeland, and Plant City (fig. 1), the upper Hillsborough River watershed has not been extensively developed and consists primarily of heavily forested floodplains, upland forests, open grazing and rangeland, extensive riverine wetlands, isolated wetlands and prairies, and some sod- and row-crop cultivation (Trommer and others, 2007). In the upper Hillsborough River watershed, land-surface altitudes range from about 40 to $100 \mathrm{ft}$ above NGVD 29. About 35 percent of the entire upper Hillsborough River watershed is agricultural land (mostly pasture and rangeland), 23 percent is urban, 19 percent is wetlands, and 21 percent is a variety of undeveloped uplands (Trommer and others, 2007).

The climate in the study area is subtropical and humid, with an average annual temperature of $72{ }^{\circ} \mathrm{F}$. The average annual precipitation from 1915 to 2005 was 53.95 in.; the maximum precipitation was 78.38 in., in 1959 , and the minimum precipitation was 31.42 in., in 2000 (Southwest Florida Water Management District, 2008). The annual precipitation for the 30-year period from 1976 to 2005 was between 37.46 and $76.09 \mathrm{in} / \mathrm{yr}$, averaging about $53.24 \mathrm{in} / \mathrm{yr}$ for the entire watershed (Southwest Florida Water Management District, 2008). About 60 percent of all rainfall occurs during the wet season from June through September during intense, localized thunderstorms, as well as occasional tropical storms and hurricanes. Winter frontal storms account for most of the rainfall from December through March.

\section{Hydrogeologic Framework}

The upper Hillsborough River watershed is underlain by a thick sequence of carbonate rocks covered by unconsolidated surficial sediments (Wolansky and Thompson, 1987) (fig. 2). "The karst nature of the landscape in the watershed is due to irregular weathering of the limestone surface, illustrated by small, localized sinkholes, sinkhole lakes (primarily on the ridges), isolated circular wetlands, and coalescence of multiple sinkholes in wetlands and lakes" (Trommer and others, 2007). 


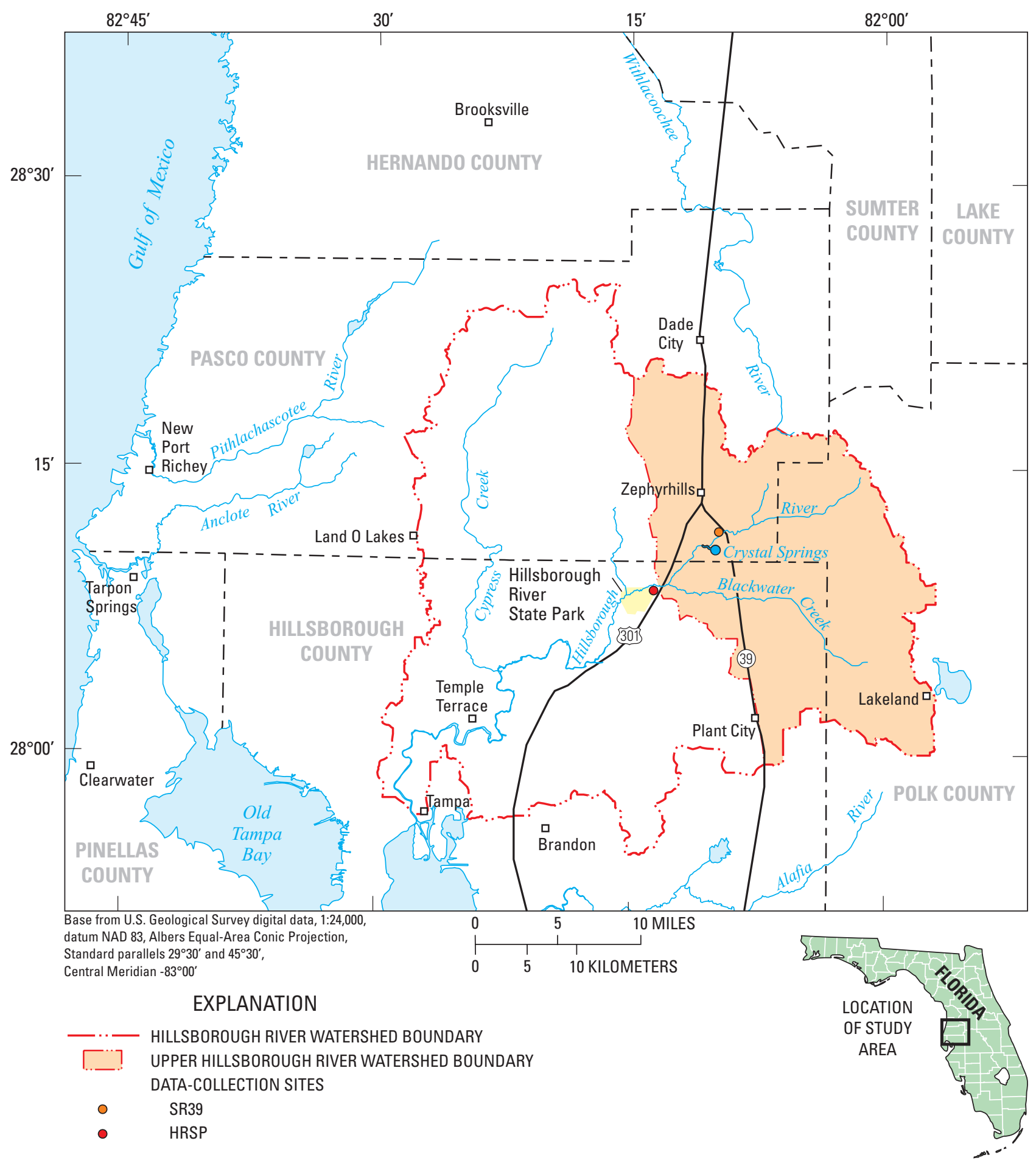

Figure 1. Study area, showing data collection sites in the upper Hillsborough River watershed and boundary of the Hillsborough River watershed. Aerial photos of SR39 and HRSP sites are shown on figures 4 and 5, respectively. 


\begin{tabular}{|c|c|c|c|c|c|}
\hline SYSTEM & \multicolumn{2}{|c|}{$\begin{array}{c}\text { STRATIGRAPHIC } \\
\text { UNIT }\end{array}$} & $\begin{array}{l}\text { GENERAL } \\
\text { LITHOLOGY }\end{array}$ & \multicolumn{2}{|r|}{$\begin{array}{c}\text { HYDROGEOLOGIC } \\
\text { UNIT }\end{array}$} \\
\hline $\begin{array}{c}\text { Holocene } \\
\text { to }\end{array}$ & \multicolumn{2}{|c|}{$\begin{array}{l}\text { Undifferentiated } \\
\text { Sands and clays }\end{array}$} & $\begin{array}{l}\text { Quartz sand, silty sand, clayey } \\
\text { sand }\end{array}$ & \multirow{2}{*}{\multicolumn{2}{|c|}{ Surficial aquifer system }} \\
\hline Pliocene & \multirow{3}{*}{ 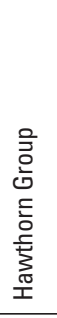 } & & $\begin{array}{l}\text { Clay, minor quartz sand, } \\
\text { phosphate, fine-grained } \\
\text { dolomite, residual limestone }\end{array}$ & & \\
\hline Miocene & & \multirow{2}{*}{$\begin{array}{l}\text { Tampa } \\
\text { Member } \\
\text { of the } \\
\text { Arcadia } \\
\text { Formation }\end{array}$} & \multirow[t]{2}{*}{$\begin{array}{l}\text { Limestone, minor quartz sand, } \\
\text { phosphate, chert, clay, fine-grained } \\
\text { dolomite }\end{array}$} & \multirow{6}{*}{ 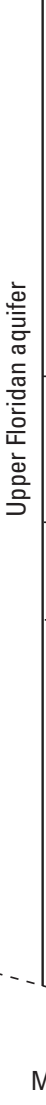 } & \\
\hline & & & & & Tampa/Suwannee \\
\hline Oligocene & $\begin{array}{l}\text { Suv } \\
\text { Lim }\end{array}$ & $\begin{array}{l}\text { inee } \\
\text { one }\end{array}$ & $\begin{array}{l}\text { Limestone, packstone to } \\
\text { grainstone, trace quartz sand, } \\
\text { organics, variable dolomite and } \\
\text { clay content, highly fossiliferous, } \\
\text { vuggy }\end{array}$ & & producing zone \\
\hline \multirow{3}{*}{ Eocene } & \multicolumn{2}{|c|}{$\begin{array}{l}\text { Ocala } \\
\text { Limestone }\end{array}$} & $\begin{array}{l}\text { Limestone, micritic, chalky, very } \\
\text { fine- to fine-grained, soft, } \\
\text { poorly indurated, trace organics, } \\
\text { clays and dolomite, abundant } \\
\text { foraminifera }\end{array}$ & & $\begin{array}{l}\text { Ocala } \\
\text { semiconfining } \\
\text { unit }\end{array}$ \\
\hline & \multirow{2}{*}{\multicolumn{2}{|c|}{$\begin{array}{l}\text { Avon Park } \\
\text { Formation }\end{array}$}} & $\begin{array}{l}\text { Limestone, dolomite, and } \\
\text { evaporites } \\
\text { Limestone and dolomite interbeds } \\
\text { typical in upper part; deeper beds } \\
\text { are continuous dolomite with in- } \\
\text { creasing evaporites at base } \\
\text { Limestone is fine-grained, tan, } \\
\text { recrystallized packstone with } \\
\text { variable amounts of organic-rich } \\
\text { laminations near top } \\
\text { Dolomite is hard, brown, sucrosic } \\
\text { in texture and commonly fractured }\end{array}$ & & $\begin{array}{l}\text { Avon Park } \\
\text { producing zone }\end{array}$ \\
\hline & & & $\begin{array}{l}\text { Evaporites present in dolomite as } \\
\text { interstitial gypsum and anhydrite, } \\
\text { with evaporite filling pore space, } \\
\text { and as interbeds in the lower part }\end{array}$ & & Middle confining unit \\
\hline
\end{tabular}

Figure 2. Generalized hydrostratigraphy of the study area (modified from Tihansky, 2005). Dashed lines where inferred.

Principal hydrogeologic units within the watershed are in descending order the surficial aquifer, the intermediate confining unit, and the Upper Floridan aquifer (fig. 2).

"The top of the surficial aquifer is contiguous with land surface and the aquifer consists of unconsolidated clastic sediments of quartz sand, clayey sand, and organic debris that range in age from Holocene to Pliocene" (Trommer and others, 2007). This unit commonly is referred to as the surficial aquifer system in areas where more than one permeable unit is present or where the deposits are interbedded (Metz and Sacks, 2002). In this report these deposits are considered to form a single aquifer referred to as the surficial aquifer, rather than a system. "The thickness of the aquifer is variable; generally, surficial deposits are thinnest near the stream channels and thickest to the south and toward the ridges" (Trommer and others, 2007). The surficial aquifer is not a substantial source of water supply in the upper Hillsborough River watershed. The surficial aquifer does, however, provide a source of water that flows to streams and recharges the Upper Floridan aquifer, either by downward vertical leakage through the confining unit or directly through breaches in the confining unit (Trommer and others, 2007). A continuous surficial aquifer does not extend across the entire study area because of the variability of the underlying confining unit (Champion and DeWitt, 2000). The surficial sediments pinch out in parts of the study area, exposing limestone in areas such as river channels where outcrops are present (fig. 3). 


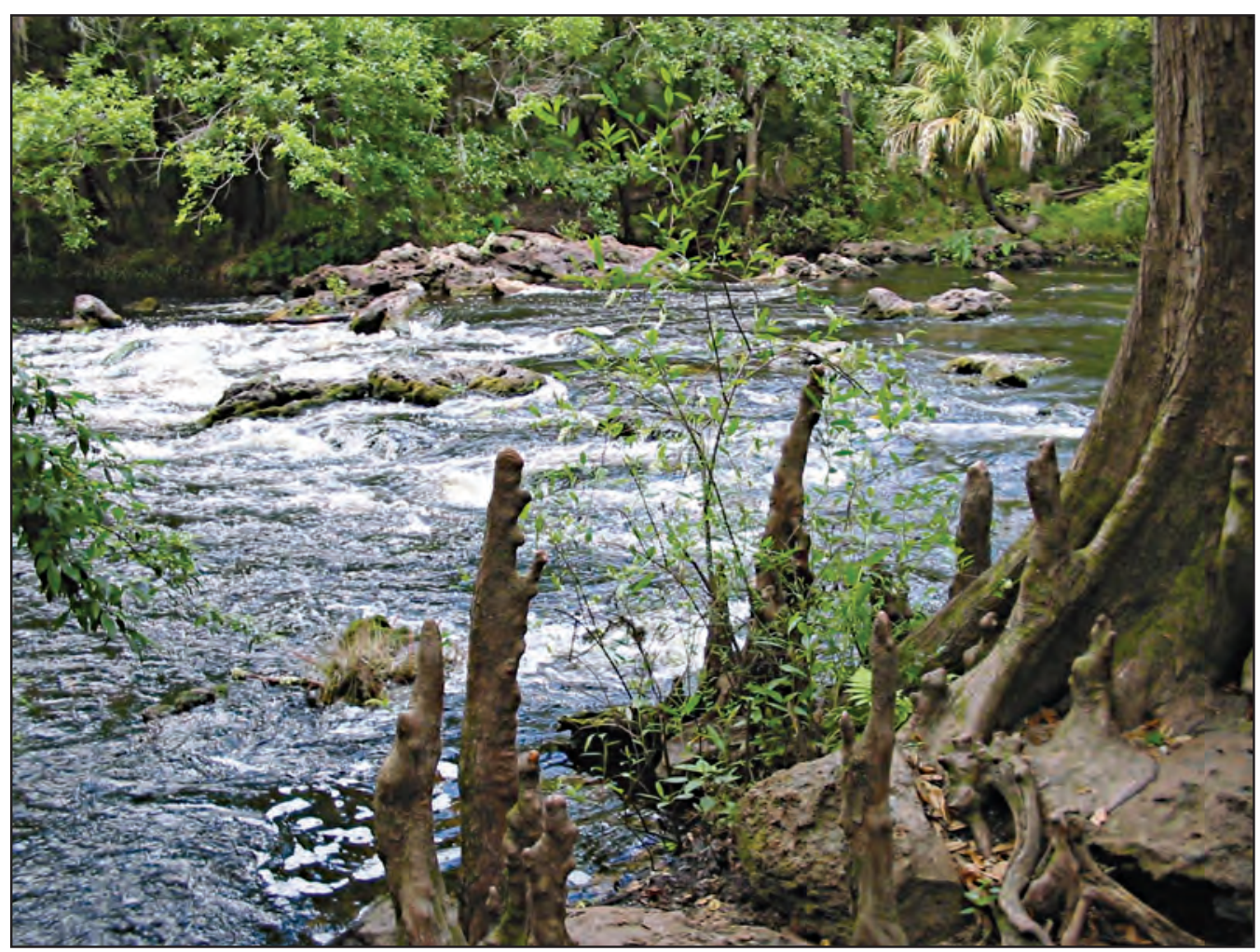

Figure 3. Limestone outcrop of the Tampa Member of the Arcadia Formation in the Hillsborough River at Hillsborough River State Park. Photograph by Dan Duerr, U.S. Geological Survey (retired).

The intermediate confining unit underlies the surficial aquifer. This semiconfining layer consists of undifferentiated deposits of the Hawthorn Group (Southeastern Geological Society, 1986), a predominantly Miocene-age clay. The Hawthorn Group can include chert as well as carbonate mud that has been described as a residuum of the limestone in the Tampa Member of the Arcadia Formation (Sinclair, 1974). The confining unit is discontinuous near the Hillsborough River channel and along the middle and lower reaches of Blackwater Creek (fig. 1), although clay outcrops are present in the stream channel and along the banks at many other locations (Trommer and others, 2007). The intermediate confining unit ranges from 0 to greater than $30 \mathrm{ft}$ thick in the study area (Southwest Florida Water Management District, 1996). The driller's log for the HRSP site "Suspension Bridge" well indicates that surficial and/or Hawthorn Group materials are present to a depth of $12 \mathrm{ft}$ below land surface.

The Upper Floridan aquifer underlies the intermediate confining unit. The aquifer is semiconfined throughout most of the study area and is unconfined in the stream valleys where the intermediate confining unit is discontinuous (Trommer and others, 2007). The Upper Floridan aquifer is a regional aquifer consisting of multiple layers of continuous limestone and dolomite, ranging in age from Eocene to Miocene. Locally, the aquifer includes the Avon Park Formation, the Ocala Limestone, the Suwannee Limestone, and the Tampa Member of the Arcadia Formation (Trommer and others, 2007). The Suwannee Limestone is commonly the first continuous limestone found in the study area below the surficial deposits and any remnant Hawthorn Group materials. The driller's log for the HRSP site well describes the material collected from 12 to $27 \mathrm{ft}$ deep as "cement-like," and indicates that it is the soft, sandy, marly upper part of the Suwannee Limestone. The limestone of the Tampa Member of the Arcadia Formation is the uppermost carbonate unit in the study area; where present, it lies close to land surface and crops out in some stream channels (Trommer and others, 2007).

\section{Methods of Investigation}

Several methods have been developed to separate base flow from streamflow (Nathan and McMahon, 1990; Lin and others, 2007). Stewart and others (2007) grouped these methods into three categories: recession-curve methods, recursivedigital filter methods, and mass-balance methods. The recession curve methods use the slope of the stream hydrograph recession to determine a basin-specific constant that represents the contribution of the groundwater system to total streamflow (Hall, 1968; Nathan and McMahon, 1990). The recession constant is thought to integrate many hydrologic and geologic characteristics of a watershed (Meyboom, 1961; Wright, 1970; Ford and Williams, 1989). Rorabaugh (1964) developed a recession curve method that was subsequently automated for use with available digital records of streamflow from USGS gaging stations (Rutledge, 1993). 
A second category of base-flow separation methods is based upon low-pass filters that separate the "low frequency" base-flow component from the "high-frequency" runoff or quick-flow component. Nathan and McMahon (1990) describe a recursive digital filter adapted from signal-processing theory where the degree of filtering is determined by adjusting a filter coefficient and selecting the number of passes the filter makes through the discharge dataset. The method provides objective and repeatable estimates of an index of base flow, but estimates are not based on hydrologic processes.

One type of analytical low-pass filter used for base-flow separation is based on the "time of cessation of runoff" (Pettyjohn and Henning, 1979). This type of filter uses a moving time window to find successive discharge minima on a hydrograph. The base-flow hydrograph is assumed to be the line connecting the selected minima. The degree of smoothing depends on the length of the time window, with longer times reducing the volume of base flow. Two automated base-flow separation procedures that use this general time-window method are the Base Flow Index (BFI) method (Wahl and Wahl, 1988) and the Hydrograph Separation (HYSEP) method (Sloto and Crouse, 1996). The BFI method is based on the Institute of Hydrology (1980) method.

In these methods, the length of the time window is dependent on the formula:

$$
N=A^{0.2}
$$

where $N$ is the time, in days, after the peak discharge where all discharge returns to base flow, and $A$ is the basin area, in square miles, above the station (Linsley and others, 1949). The only basin variable considered in this method is basin area. The cessation of surface runoff also depends on (1) other watershed characteristics, including directly connected impervious cover, average topographic slope, infiltration capacities, and drainage density; (2) the dynamic characteristics of the groundwater system; and (3) storage features, including riparian wetlands, depressions, banks, and floodplains.

Low-pass filters, including base-flow recession or runoff cessation methods, are not well suited to hydrologic conditions in west-central Florida, where infiltration rates are often highly variable and surface slopes are gradual. For most graphical base-flow separation methods, $N$ is typically assigned a time-period value of 1-5 days in equation 1 , which is too short a time period for the poorly integrated drainage systems of west-central Florida (Ross and others, 1997; Stewart and others, 2007).

Halford and Mayer (2000) provide several examples of discrepancies in estimates of base flow between groundwater discharge estimation methods and base-flow recession methods. They assert that because the major assumptions of the base-flow recession methods are commonly and grossly violated, streamflow records alone cannot be used to determine base flow. They recommend the use of multiple methods, including geochemical tracers, because the accuracy of any single base-flow separation method is difficult to assess.
The third category of base-flow separation methods consists of chemical mass-balance models that assume streamflow is composed of distinct flow components having a characteristic concentration of one or more conservative chemical constituents (Pinder and Jones, 1969; Fritz and others, 1976). Discrete or periodic streamflow samples are analyzed for selected, conservative constituents over a range of hydrologic conditions. For base-flow separations, two components are commonly determined: (1) pre-event water, consisting of unsaturated-zone water and groundwater; and (2) event water, consisting of overland flow and subsurface stormflow (Hooper and Shoemaker, 1986; Wels and others, 1991; Cey and others, 1998). The application of three-component (pre-event water, precipitation, and event water) mass-balance methods is typically limited to individual storms in small headwater basins, usually less than $0.39 \mathrm{mi}^{2}$, because of the required intensity of temporal and spatial sampling and analysis of the chemical constituents (Rice and Hornberger, 1998; Scanlon and others, 2001). Results from a meso-scale basin investigation by Uhlenbrook and others (2002) indicate that two-component separations may be more reasonable for larger basins than the small, high-relief headwater basins typically studied with three-component separations.

Hydrograph separation using isotopic-tracer mass-balance methods can provide valuable insight into processes affecting streamflow (Kendall and McDonnell, 1998). However, most isotopic hydrograph separation studies have been conducted in northern climates (Buttle, 1994), rather than in subtropical or tropical climates where evaporative losses during transit can be large (Gremillion and Wanielista, 2000). Isotopic and geochemical methods can be impractical for long-term streamflow applications. Consequently, shorter-term isotopic and geochemical measurements of base flow combined with longterm measurements of streamflow and specific conductance may be useful for selecting and calibrating graphical methods that can then be applied to existing streamflow records over longer periods.

\section{Data Collection Sites}

Two data-collection sites on the upper Hillsborough River were selected: Hillsborough River at State Road 39 and Hillsborough River at the State Park (fig. 1), referred to herein as the SR39 and HRSP sites, respectively. Surface-water and groundwater data were collected at both sites. These sites were selected because of their location in the upper part of the Hillsborough River watershed and their direct connection to the Upper Floridan aquifer. Aquifer/stream interconnection in the area is indicated by groundwater hydraulic gradients toward streams, and potentiometric contours that bend upstream in the vicinity of the Hillsborough River on both wet and dry season potentiometric maps (Trommer and others, 2007). The gaged areas of the SR39 and HRSP sites cover $72.5 \mathrm{mi}^{2}$ and $220 \mathrm{mi}^{2}$ of the watershed, respectively. The SR39 site is about $5 \mathrm{mi}$ upstream from the HRSP site and the drainage of the SR39 site 
Table 1. Surface-water data-collection sites.

[Surface-water site locations are shown in figures 4 and 5]

\begin{tabular}{|c|c|c|c|}
\hline \multicolumn{2}{|l|}{ Site name } & \multirow[b]{2}{*}{ Data type } & \multirow[b]{2}{*}{ Period of record } \\
\hline Name and site ID & $\begin{array}{l}\text { In this } \\
\text { report }\end{array}$ & & \\
\hline $\begin{array}{l}\text { Hillsborough River near } \\
\text { Zephyrhills FL (02303000) }\end{array}$ & HRSP & Mean daily discharge & October 1939 to present \\
\hline
\end{tabular}

${ }^{1}$ Mean daily discharge period of record is February 1, 2003, to May 30, 2005.

constitutes 33 percent of the drainage of the HRSP site. Direct connection between the Hillsborough River and the Upper Floridan aquifer may be an important factor for distinguishing base flow from runoff because of differences in chemical constituents.

Hydrologic data (precipitation, throughfall, streamflow, and water levels) and water-quality data were collected during low-flow and stormflow conditions at both sites. Throughfall refers to the precipitation that reaches the ground after passing through the tree canopy.

\section{Hydrologic Data Collection}

Continuous streamflow and specific conductance were measured at the SR39 and HRSP surface-water sites (table 1). The SR39 site (USGS identifier 02301988), was established solely to fulfill the purpose of this study, and recorded data from February 1, 2003, to April 30, 2005 (fig. 4). The HRSP site (USGS identifier 02303000), is a long-term streamflow monitoring station that has been operational since October 1939, with 70 years of record (fig. 5). Each station was equipped to measure river stage and surface-water specific conductance, as well as to relay data to the office using satellite telemetry so storm events could be monitored. A stagedischarge relation was developed for each site to calculate streamflow from continuous stage data (Rantz and others, 1982). In addition, records of mean daily discharge were compiled for the Hillsborough River at the SR39 and the HRSP sites from February 1, 2003, to April 30, 2005. Precipitation and throughfall amounts were measured at each site using two bulk precipitation samplers: one located under the river margin canopy near the bank of the river, and the other located in an open canopy perpendicular to the river channel (table 2). Precipitation rates were measured weekly.

Groundwater levels were measured in monitoring wells along two transects (figs. 4 and 5). Along these transects, hydrogeologic cross sections were constructed using data from previous reports and from drilling activities conducted as part of this study (figs. 6 and 7, table 3). Transect $A-A$ ' crosses the Hillsborough River at the SR39 site and consists of a SWFWMD Regional Observation and Monitor-well Program well (ROMP 86A SWNN) on the north end, a USGS well (1-Deep) on the south end, and a USGS well (3-North) near the river (fig. 6). The three wells are finished in the Upper Floridan aquifer within the Suwannee Limestone, at depths of 135,112 , and $19 \mathrm{ft}$ below land surface, respectively (table 3 ). Transect $B-B$ ' is located on the south side of the Hillsborough River at the HRSP site and consists of a shallow USGS well ("Suspension Bridge") on the north end and two SWFWMD wells ("Parking Lot Shallow" and "Parking Lot Deep") at the south end (fig. 7). The three wells are finished into the Upper Floridan aquifer within the Suwannee Limestone, at depths of $11.75,37$, and $50 \mathrm{ft}$ below land surface, respectively. A semi-confining bed was not observed in transect $B-B$ '. Monitoring wells and reference points at both transects were leveled to NGVD 29. Groundwater-level data were collected at approximately 1 -week intervals.

\section{Water-Quality Data Collection}

Water-quality samples were collected at surface-water, groundwater, and precipitation sites from 2003 to 2005 and 2009. Surface-water samples were collected from the river channel, and groundwater samples were collected from three monitoring wells at each site. Bulk precipitation samples were collected weekly and composited monthly, surface-water samples were collected monthly, and groundwater samples were collected quarterly during this study. During storm events, surface-water samples were collected manually or using an automatic sampler at variously programmed time intervals in addition to the monthly samples. Non-stormwater surface-water samples were vertically integrated manually at the midpoint of the stream channel; storm surface-water samples were point samples collected either manually near the intake or at the intake of an automatic sampler. Precipitation samples were collected using the bulk precipitation samplers described earlier. An automatic sampler was established in the upland area near the SR39 site for collecting precipitation during periods of rainfall (table 2). 


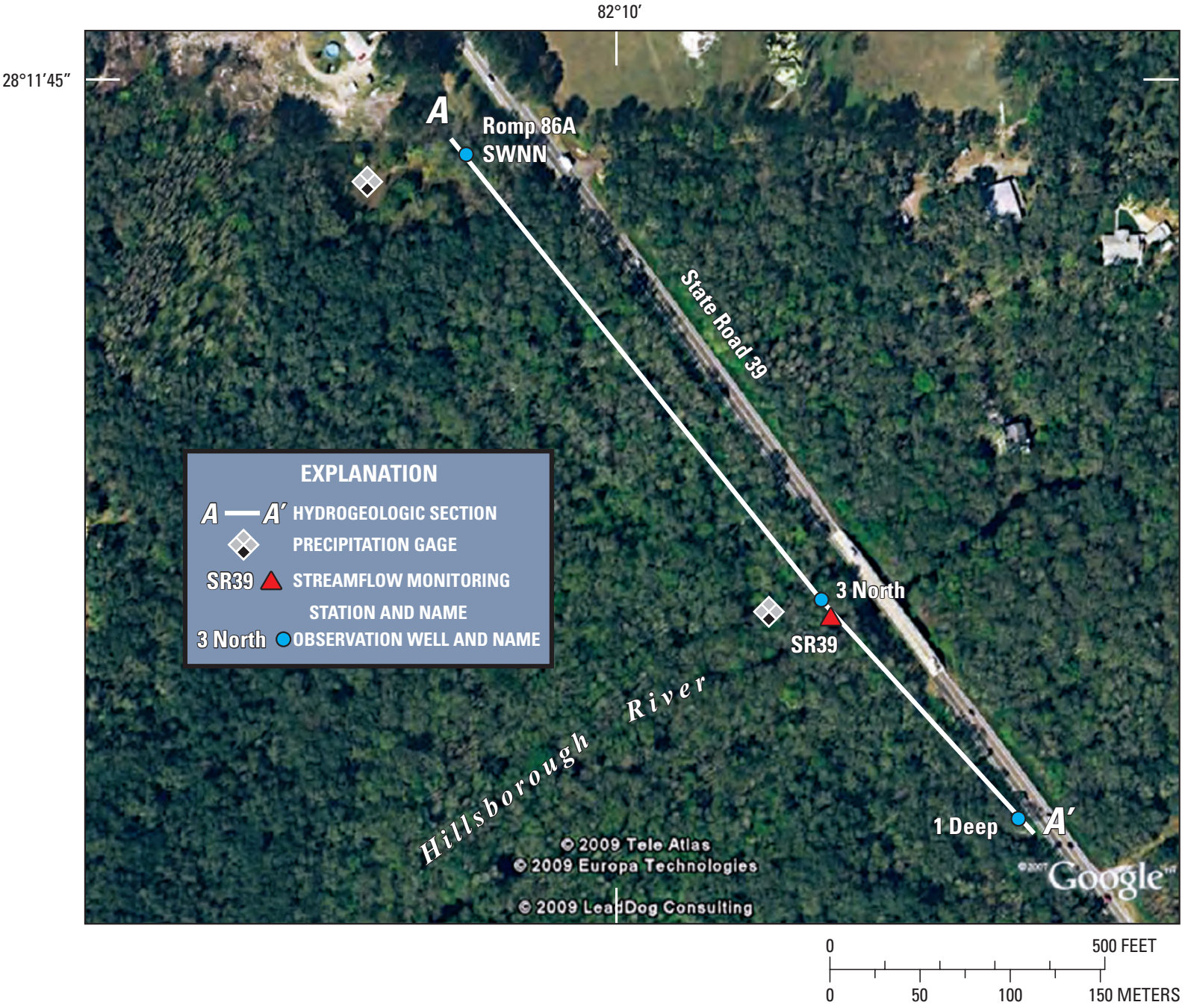

Figure 4. Data collection locations at the SR39 site (transect $A-A^{\prime}$ shown in figure 6). 


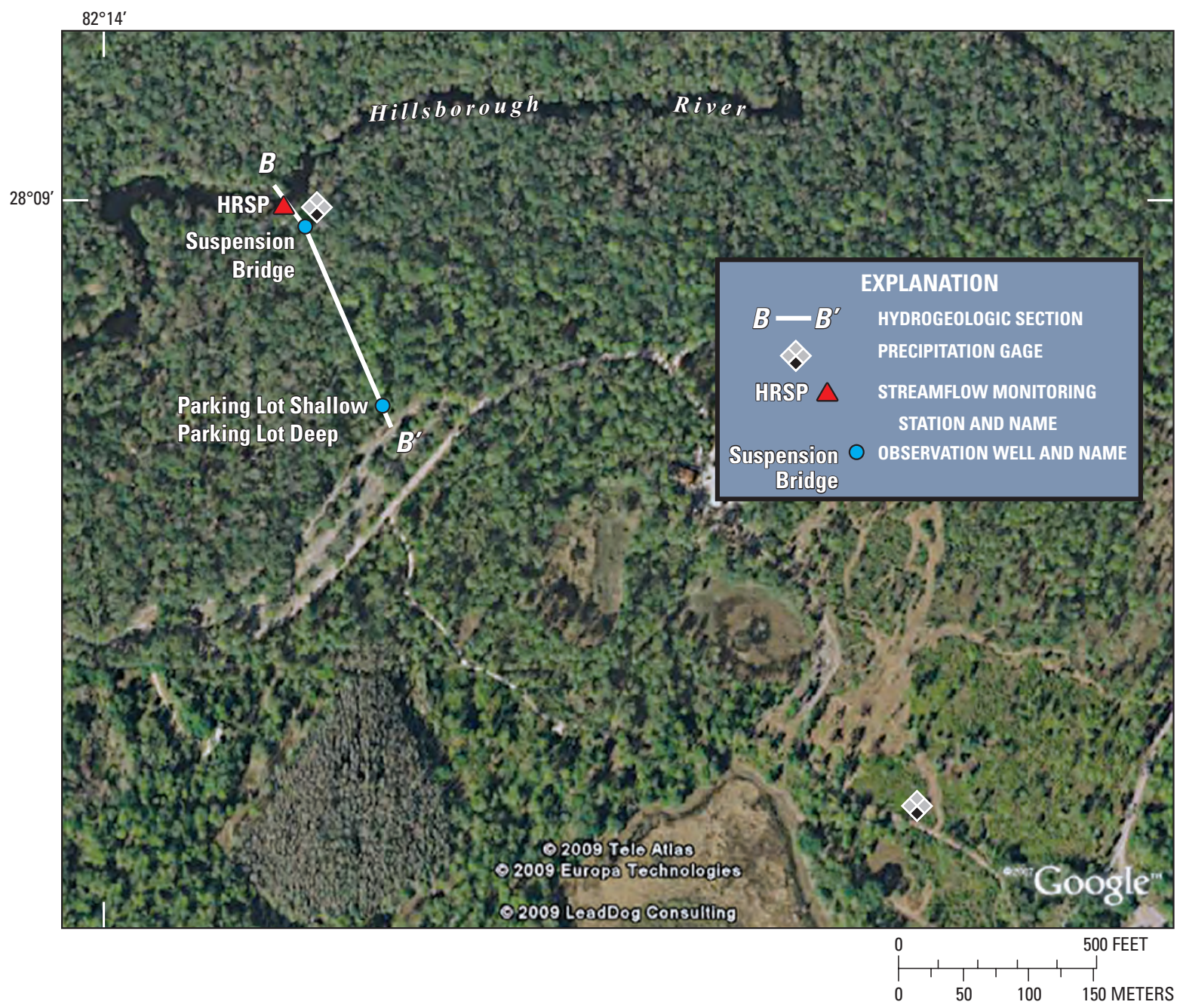

Figure 5. Data collection locations at the HRSP site (transect $B-B^{\prime}$ shown in figure 7). 
Table 2. Precipitation data-collection sites.

[All data collection sites collect weekly bulk precipitation and monthly precipitation data. Rainfall site locations are shown in figures 4 and 5.]

\begin{tabular}{|c|c|c|}
\hline Location & Exposure & Canopy type \\
\hline $\begin{array}{l}\text { West upland of Hillsbor- } \\
\text { ough River downstream } \\
\text { of SR39 site }\end{array}$ & Open canopy & $\begin{array}{l}\text { Upland } \\
\text { Canopy: none } \\
\text { Understory: pasture grass }\end{array}$ \\
\hline $\begin{array}{l}\text { West floodplain of Hillsbor- } \\
\text { ough River downstream } \\
\text { of SR39 site }\end{array}$ & Throughfall & $\begin{array}{l}\text { River margin } \\
\text { Canopy: laurel oak (Quercus } \\
\text { laurifolia), cabbage palm (Sabal } \\
\text { palmetto) } \\
\text { Understory: red maple (Acer } \\
\text { rubrum, wild coffee (Psychotria } \\
\text { nervosa) }\end{array}$ \\
\hline $\begin{array}{l}\text { Upland near center of } \\
\text { HRSP site }\end{array}$ & Open canopy & $\begin{array}{l}\text { Upland } \\
\text { Canopy: none } \\
\text { Understory: Saw palmetto (Sere- } \\
\text { noa repens); actively burned } \\
\text { area }\end{array}$ \\
\hline $\begin{array}{l}\text { Floodplain adjacent to } \\
\text { USGS gage on Hillsbor- } \\
\text { ough River in HRSP site }\end{array}$ & Throughfall & $\begin{array}{l}\text { River margin } \\
\text { Canopy: live oak (Quercus virgin- } \\
\text { iana), laurel oak (Q. laurifolia), } \\
\text { cabbage palm (S. palmetto) } \\
\text { Understory: red maple }(\text { A. ru- } \\
\text { brum), wild coffee }(P . \text { nervosa })\end{array}$ \\
\hline
\end{tabular}

Table 3. Groundwater data-collection sites.

[Well locations are shown in figures 4 and 5. All wells extend into the Upper Floridan aquifer.]

\begin{tabular}{lll}
\hline USGS well identifier & \multicolumn{1}{c}{ Well name } & $\begin{array}{c}\text { Depth of well } \\
\text { (feet) }\end{array}$ \\
\hline \multicolumn{1}{c}{ SR39 site } \\
\hline 281136082095602 & 3-North & 19.0 \\
281130082095000 & 1-Deep & 112.0 \\
281144082100402 & ROMP 86A SWNN & 135.0 \\
\hline \multicolumn{3}{c}{ HRSP site } \\
\hline SB-1 & Suspension Bridge & 11.75 \\
280852082135601 & Parking Lot Deep & 50.0 \\
\hline
\end{tabular}


$A$, Wet season

$\boldsymbol{A}$

$\boldsymbol{A}^{\prime}$

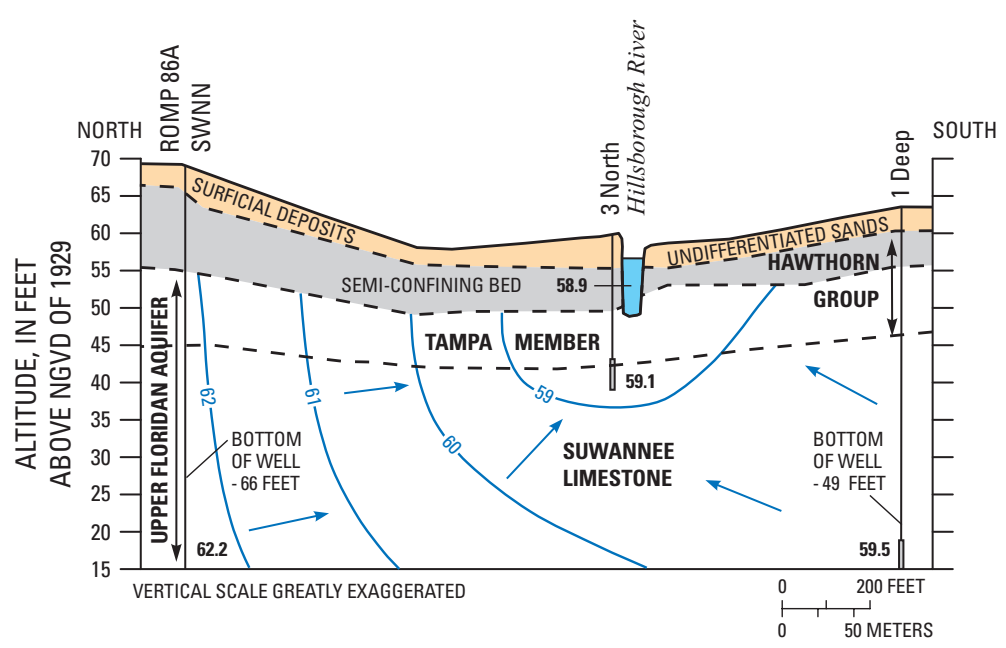

EXPLANATION

— 60 — LINE OF EQUAL HYDRAULIC HEAD - In feet above

NGVD of 1929. Contour interval is 1 foot.

GROUNDWATER FLOW DIRECTION

59.5 HYDRAULIC HEAD - In feet above NGVD of 1929

\. WELL - Showing altitude of top of screen

\section{$B$, Dry season}

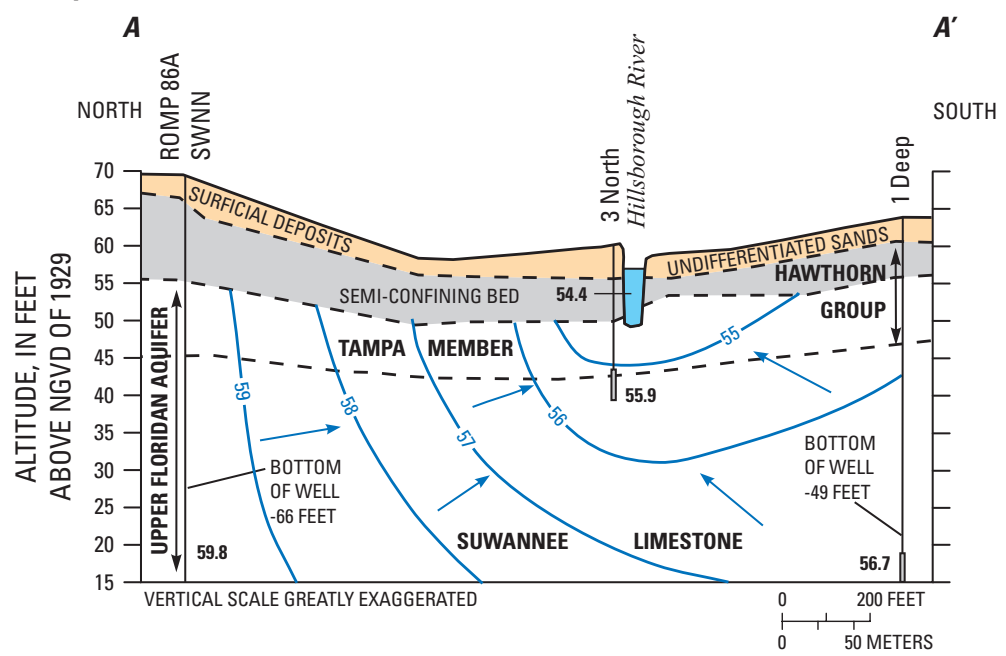

Figure 6. Hydrogeologic section $\left(A-A^{\prime}\right)$ and groundwater flow during the $A$, wet season (July 12, 2003) and $B$, dry season (February 11, 2005) at the SR39 site (modified from Trommer and others, 2007).

\section{$A$, Wet season}

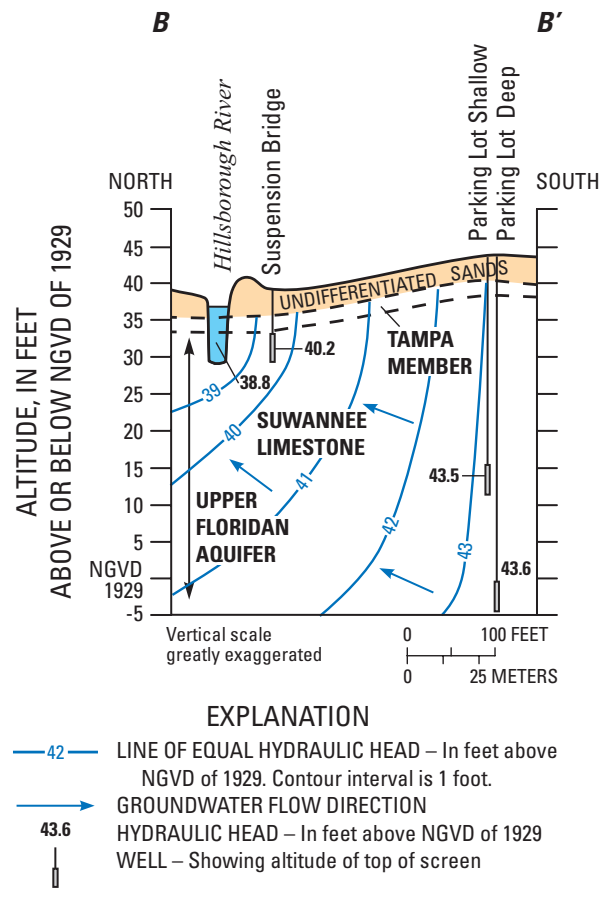

$B$, Dry season

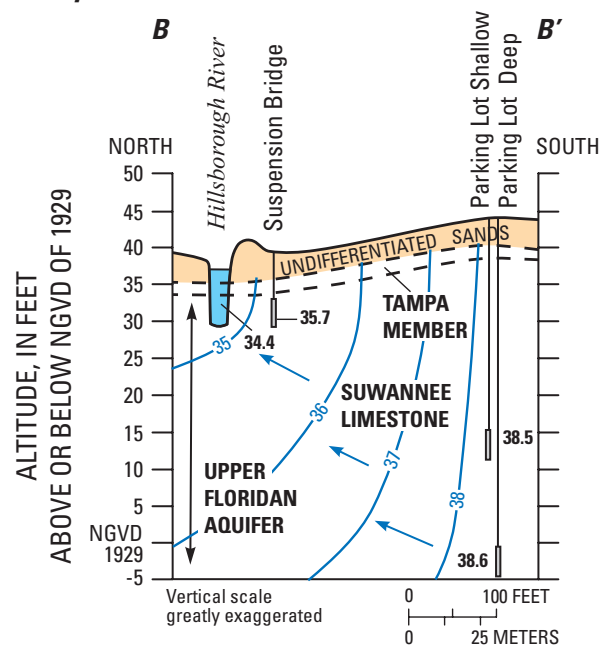

Figure 7. Hydrogeologic section $\left(B-B^{\prime}\right)$ and groundwater flow during the $A$, wet season (July 12, 2003) and $B$, dry season, (February 11, 2005) at the HRSP site. 


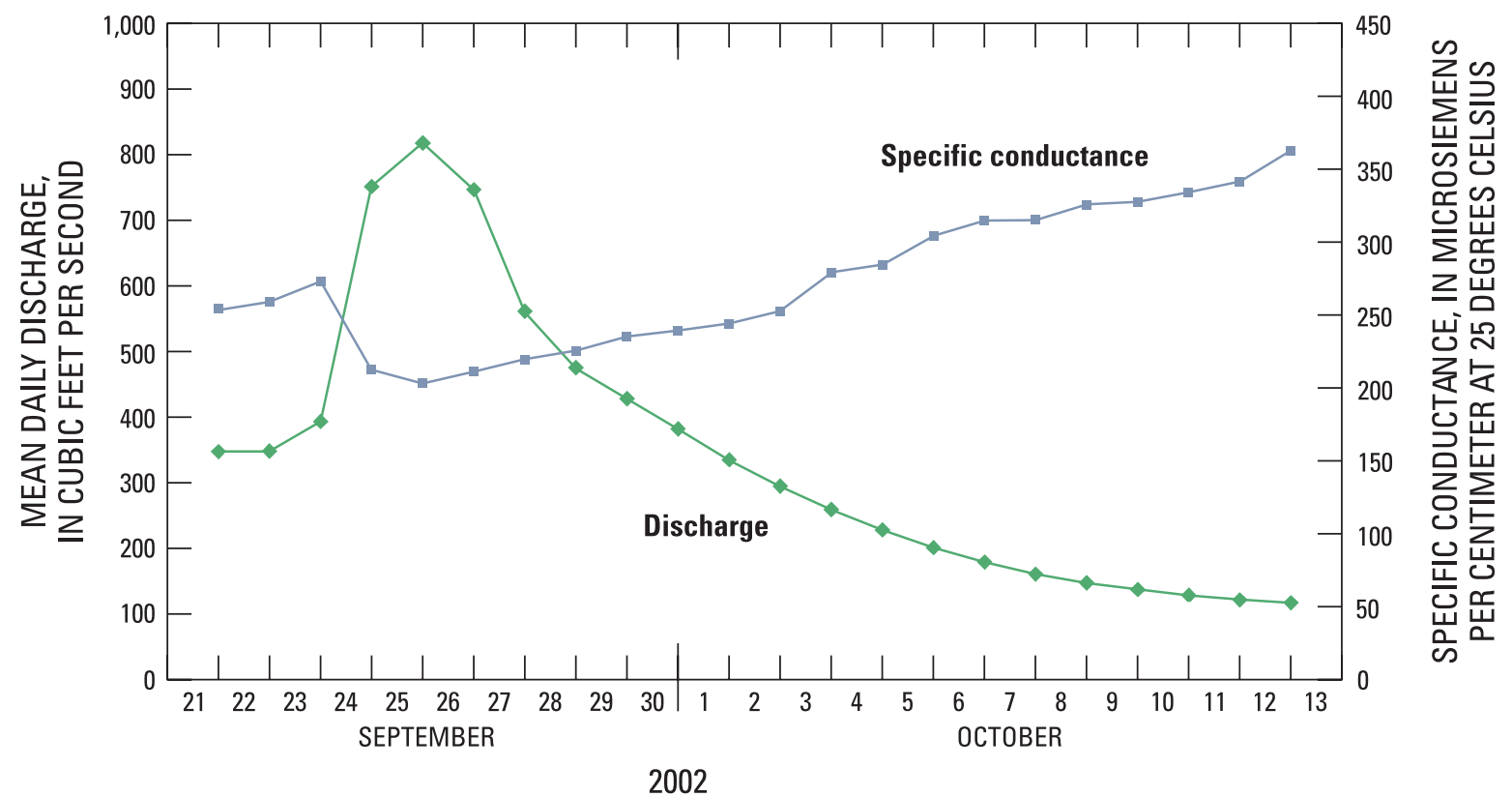

Figure 8. Daily average discharge and maximum and minimum specific conductance during a storm event at station 2303000, Hillsborough River near Zephyrhills, Florida (reprinted from Stewart and others, 2007 and published with permission).

Specific conductance, temperature, $\mathrm{pH}$, and dissolved oxygen were measured in the field using a YSI 556 multiparameter water-quality instrument. Sampling and field-processing equipment conformed to the USGS protocols for preventing sample contamination or loss (U.S. Geological Survey, variously dated). Quality-assurance samples (blanks and replicates) were collected for about 10 percent of the samples.

\section{Laboratory Analysis}

Major cation and anion analyses and dissolved organic carbon analyses were conducted at the USGS National WaterQuality Laboratory, Denver, Colorado and at the University of South Florida Center for Water Analysis in Tampa, Florida, using analytical methods approved by the USGS and the U.S. Environmental Protection Agency (Clesceri and others, 1999). Bicarbonate concentrations were initially calculated from inflection-point titration values and then estimated from fixed endpoint titration values. A comparison of inflection-point titrations and fixed end-point titrations yielded similar values. Strontium isotopes were analyzed by the USGS Strontium Isotope Laboratory in Menlo Park, California, using the inductively coupled plasma-mass spectrometry method (Bullen and Kendall, 1998).

Deuterium $\left({ }^{2} \mathrm{H}\right)$ and oxygen-18 $\left({ }^{18} \mathrm{O}\right)$ samples were analyzed at the USGS Stable Isotope Laboratory, in Reston, Virginia and the University of California at Davis, Department of Geology Stable Isotope Laboratory. Deuterium was analyzed using the hydrogen equilibration method (Revesz and Coplen, 2006), and ${ }^{18} \mathrm{O}$ was analyzed using the carbon-dioxide equilibration method (Epstein and Mayeda, 1953). Isotope results are reported in the conventional delta notation $(\delta)$ :

$$
\delta=\left(\frac{R_{\text {sample }}-R_{\text {standard }}}{R_{\text {standard }}}\right) \times 1,000
$$

where $R$ is the ratio ${ }^{2} \mathrm{H} / \mathrm{H}$ or ${ }^{18} \mathrm{O} /{ }^{16} \mathrm{O}$ for ${ }^{2} \mathrm{H}$ and ${ }^{18} \mathrm{O}$, respectively; $R_{\text {sample }}$ refers to the isotope ratio of the environmental sample and $R_{\text {standard }}$ refers to the isotope ratio for Vienna Standard Mean Ocean Water (VSMOW) (Craig, 1961). The resulting sample values of delta deuterium $\left(\delta^{2} \mathrm{H}\right)$ and delta oxygen-18 $\left(\delta^{18} \mathrm{O}\right)$ are reported in per mil deviation relative to VSMOW and, by convention, the $\delta^{2} \mathrm{H}$ and $\delta^{18} \mathrm{O}$ of VSMOW are set at 0 per mil (Gonfiantini, 1978). Analytical precision exceeded 2.0 and 0.2 per mil for ${ }^{2} \mathrm{H}$ and ${ }^{18} \mathrm{O}$ analyses, respectively.

\section{Mass-Balance Mixing Methods}

Base flow for selected low- and high-intensity storm hydrographs was estimated by the GMB method using major ion chemistry, and by the CMB method using point and continuous specific conductance of the water sampled throughout the storm. The specific ions used in the GMB method included calcium, magnesium, potassium, sodium, silica, chloride, and sulfate.

The GMB method evaluated the mixing of base flow and runoff during selected low- and high-intensity storms using an equation originally proposed by Steele (1968) and Pinder and Jones (1969). Stewart and others (2007) used this approach to estimate base flow from specific conductance. Figure 8 provides an example of the terms used in the following equation: 
Table 4. Annual, wet season, and dry season precipitation in the upper Hillsborough River watershed for the study period and from 1976 to 2005.

\begin{tabular}{|c|c|c|c|c|c|c|}
\hline Year or statistic & $\begin{array}{l}\text { Annual wet } \\
\text { season rainfall } \\
\text { (June-Sept.) }\end{array}$ & $\begin{array}{c}\text { Departure from } \\
30 \text {-year wet } \\
\text { season annual } \\
\text { mean }\end{array}$ & $\begin{array}{l}\text { Annual dry } \\
\text { season rainfall } \\
\text { (Oct.-May) }\end{array}$ & $\begin{array}{l}\text { Departure } \\
\text { from 30-year } \\
\text { dry season } \\
\text { annual mean }\end{array}$ & $\begin{array}{l}\text { Annual } \\
\text { rainfall }\end{array}$ & $\begin{array}{c}\text { Departure from } \\
\text { 30-year annual } \\
\text { mean }\end{array}$ \\
\hline \multicolumn{7}{|c|}{ Study period (2003-2005) } \\
\hline 2003 & 33.47 & 2.75 & 34.05 & 11.53 & 67.52 & 14.28 \\
\hline 2004 & 49.26 & 18.54 & 21.06 & -1.46 & 70.32 & 17.08 \\
\hline 2005 & 30.54 & -0.18 & 18.32 & -4.20 & 48.86 & -4.38 \\
\hline \multicolumn{7}{|c|}{ 30-year period (1976-2005) } \\
\hline $\begin{array}{l}\text { 30-year annual } \\
\text { minimum }\end{array}$ & 22.59 & & 10.29 & & 37.46 & \\
\hline $\begin{array}{l}\text { 30-year annual } \\
\text { mean }\end{array}$ & 30.72 & & 22.52 & & 53.24 & \\
\hline $\begin{array}{l}\text { 30-year annual } \\
\text { maximum }\end{array}$ & 49.26 & & 44.34 & & 76.09 & \\
\hline
\end{tabular}

$$
Q_{B F}=Q_{\text {stream }}\left[\frac{\left(C_{\text {stream }}-C_{R O}\right)}{\left(C_{B F}-C_{R O}\right)}\right],
$$

where

$Q_{B F}$ is predicted base-flow discharge, in cubic feet per second;

$Q_{\text {stream }}$ is measured stream discharge, in cubic feet per second;

$C_{\text {stream }}$ is measured specific conductance, in microsiemens per centimeter at 25 degrees Celsius, or ion concentration in milligrams per liter of discharge at any timestep,

$C_{R O}$ is estimated end member concentration in runoff discharge as specific conductance in microsiemens per centimeter at 25 degrees Celsius, or ion concentration in milligrams per liter; and

$C_{B F}$ is estimated end member concentration in base flow discharge as specific conductance in microsiemens per centimeter at 25 degrees Celsius, or ion concentration in milligrams per liter, just prior to the event (pre-event flow).

Results are presented as a percentage of the total storm discharge attributed to base flow by using the following equation:

$$
\left(\frac{Q_{B F}}{Q_{\text {stream }}}\right) \times 100=\left(\%_{B F}\right) \text {, }
$$

where $\%_{B F}$ is percentage of total stormflow discharge composed of base flow. Total storm base-flow contributions are reported as an average percentage, because each constituent value gives a unique estimate of base flow throughout a storm.

\section{Hydrologic Characteristics, Water Quality, and Application of Base-Flow Separation Techniques}

Precipitation and discharge amounts, groundwater levels, water quality, and the application of conductance and GMB methods for determining base flow are described herein. The water-quality section discusses differences between precipitation, groundwater, and streamflow quality. The GMB method section includes results for each storm and an example showing how to calculate base flow with the GMB method.

\section{Precipitation, Surface-Water Discharge, and Groundwater Flow Gradients}

Dry season rainfall (October-May) was substantially above average during the first year of the study (2003), slightly below average for 2004, and below average for 2005 . Wet season rainfall (June-September) was slightly above average for 2003, substantially above average for 2004, and about average for 2005 (table 4).

Daily precipitation was similar at both sites with the exception of June 17, 2003, when 0.87 and 4.3 in. were recorded at the SR39 and HRSP sites, respectively (fig. 9). Daily and weekly composite precipitation amounts also were similar at the SR39 and HRSP sites (fig. 10). Monthly composite open-canopy precipitation and throughfall amounts differed by less than 1 percent, on average, at each site over the study period. 

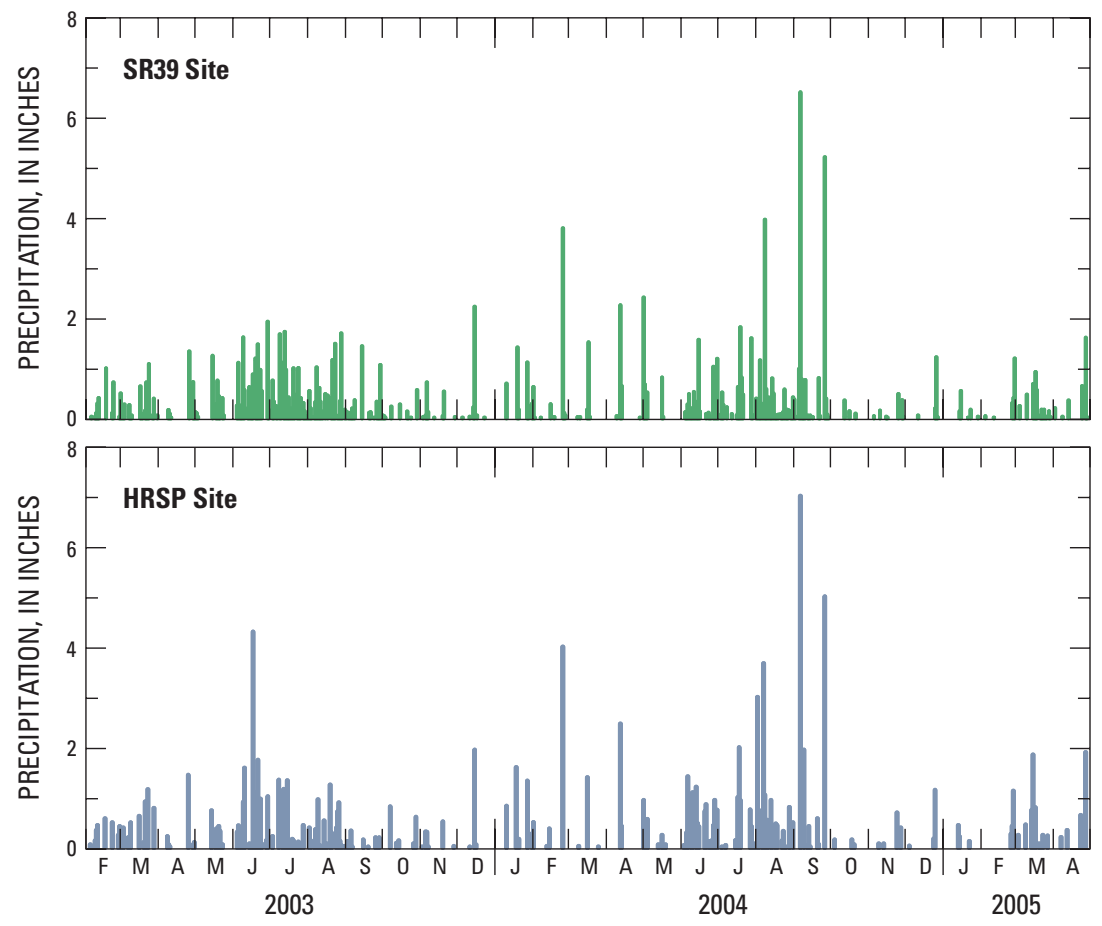

Figure 9. Daily precipitation at the SR39 and HRSP study areas from February 1, 2003, to June 1, 2005.
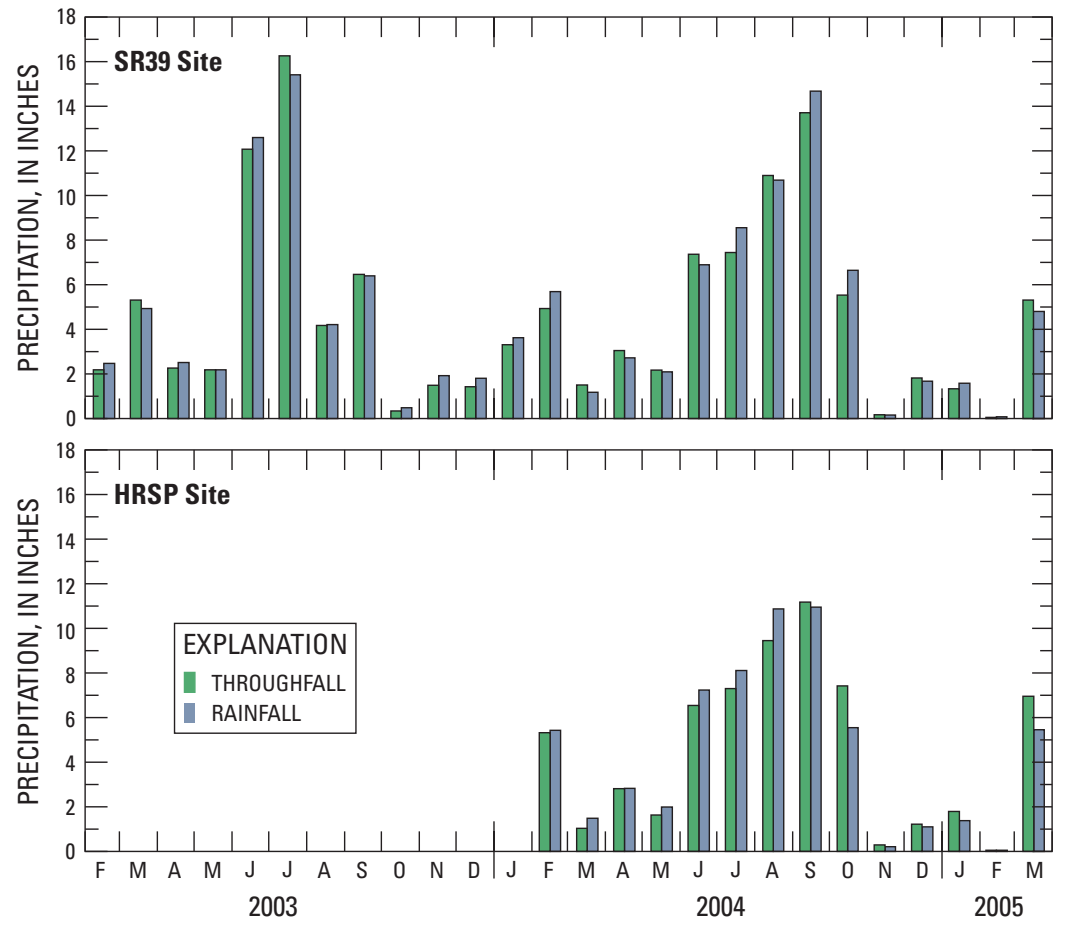

Figure 10. Weekly throughfall and total precipitation at the SR39 and HRSP study areas from February 1, 2003, to March 30, 2005. 


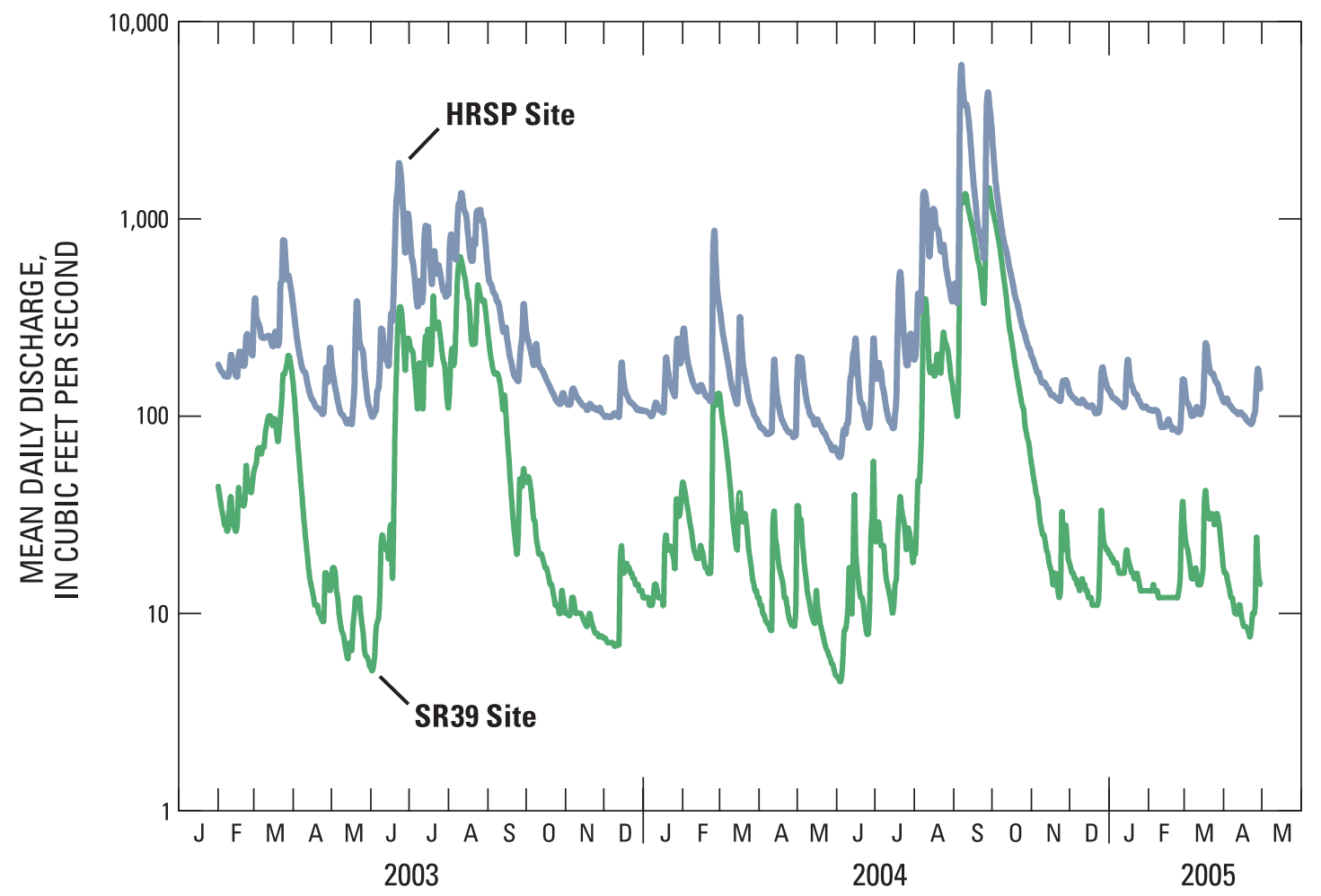

Figure 11. Hydrographs of mean daily discharge for the SR39 and HRSP sites from February 1, 2003, to April 30, 2005.

Records of mean daily discharge were compiled for the Hillsborough River at the SR39 and the HRSP sites from February 1,2003 , to May 30, 2005. The magnitude and seasonal patterns of mean daily discharge, in cubic feet per second, varied widely over the study period. A comparison of the hydrographs indicates similar patterns at the two sites, but substantially different magnitudes during individual storm events (fig. 11). The HRSP site has a substantially greater drainage area, which accounts for the greater mean annual discharge and peak discharges at that site. These patterns were expected to be similar because the portion of the watershed at the SR39 site is contained in the larger watershed of the HRSP site.

At the SR39 site, storms that occurred in March 2003, September 2003, March 2004, August-November 2004, January 2005, and February 2005 were selected for analysis. At the HRSP site, storms that occurred in July 2004, August-November 2004, January 2005, February 2005, and September 2009 were selected for analysis.

Discharge-duration curves are cumulative frequency curves showing the percentage of time that the daily mean discharge of a stream equals or exceeds a given value during a specific time period. The shape of the curve reflects the characteristics of the watershed upstream from the station. A flat slope indicates floodplain storage or a high base-flow component, whereas a steeper slope indicates less storage or less sustained base flow (Searcy, 1959). Discharge-duration curves were developed for the SR39 site for the 2003-2005 calendar years and for the HRSP site for the 2003-2009 calendar years, to determine the discharge duration for the sampled storms. Stormwater samples for the SR39 and HRSP sites were collected when mean daily discharges were equaled or exceeded between 1 and 85 percent of the time (fig. 12). The low slope of the discharge-duration curves for both sites indicates floodplain storage or a high base-flow component.

Groundwater levels measured weekly at the six Upper Floridan aquifer wells in transects $A$ and $B$ increased with depth and were generally higher than river stage, indicating the potential for upward movement of groundwater into the shallower zones of the Upper Floridan aquifer, the surficial aquifer, and surface streams in the study area (figs. 13 and 14, table 3). Head gradients in the Upper Floridan aquifer were consistently upward and toward the river during both wet and dry seasons (figs. 6 and 7) except there was little upward gradient between the deep and shallow parking lot wells at the HRSP site. 

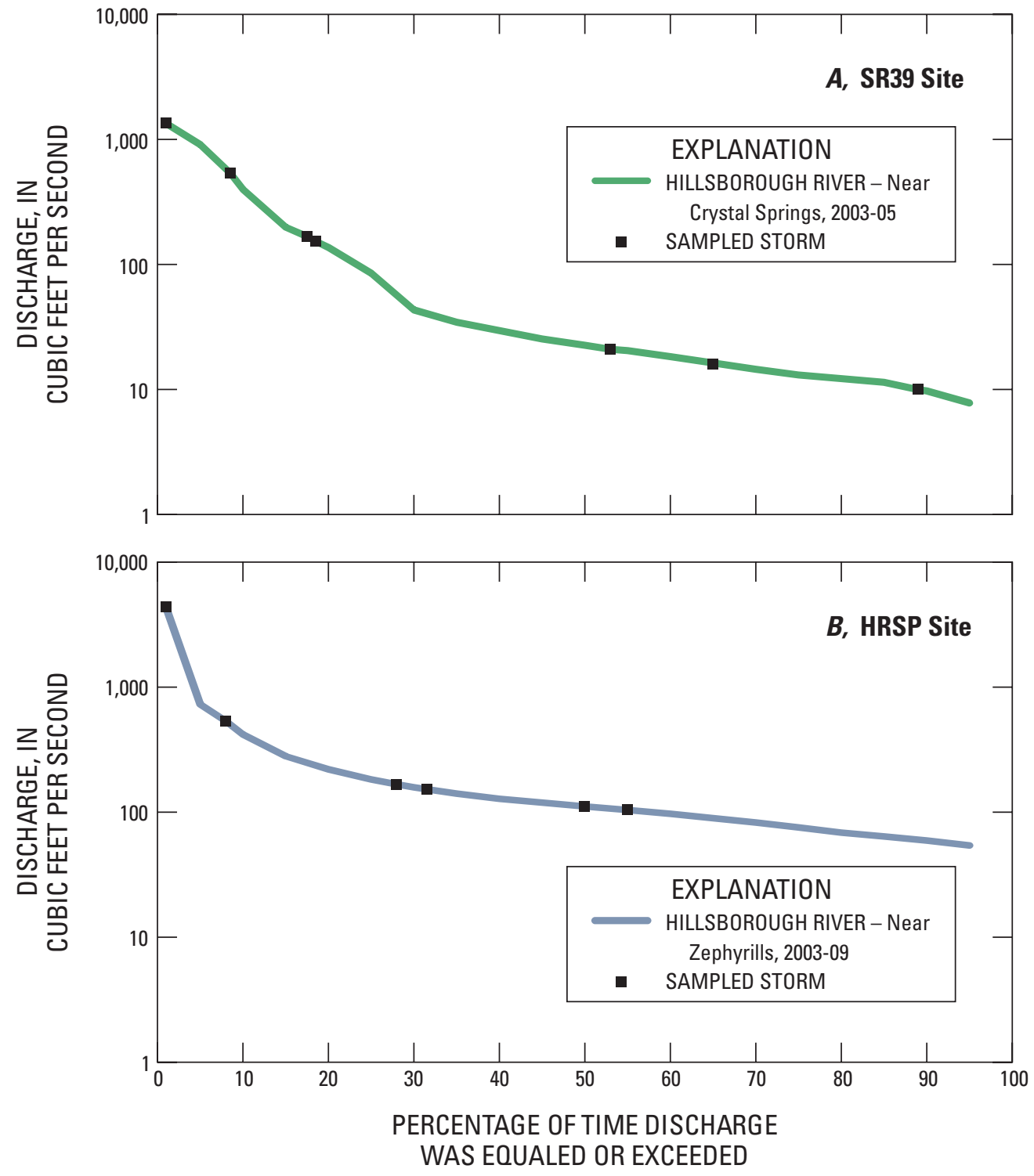

Figure 12. Duration curves of mean daily discharge for $A$, the SR39 site for calendar years 2003-2005, and $B$, the HRSP site for calendar years 2003-2009. 


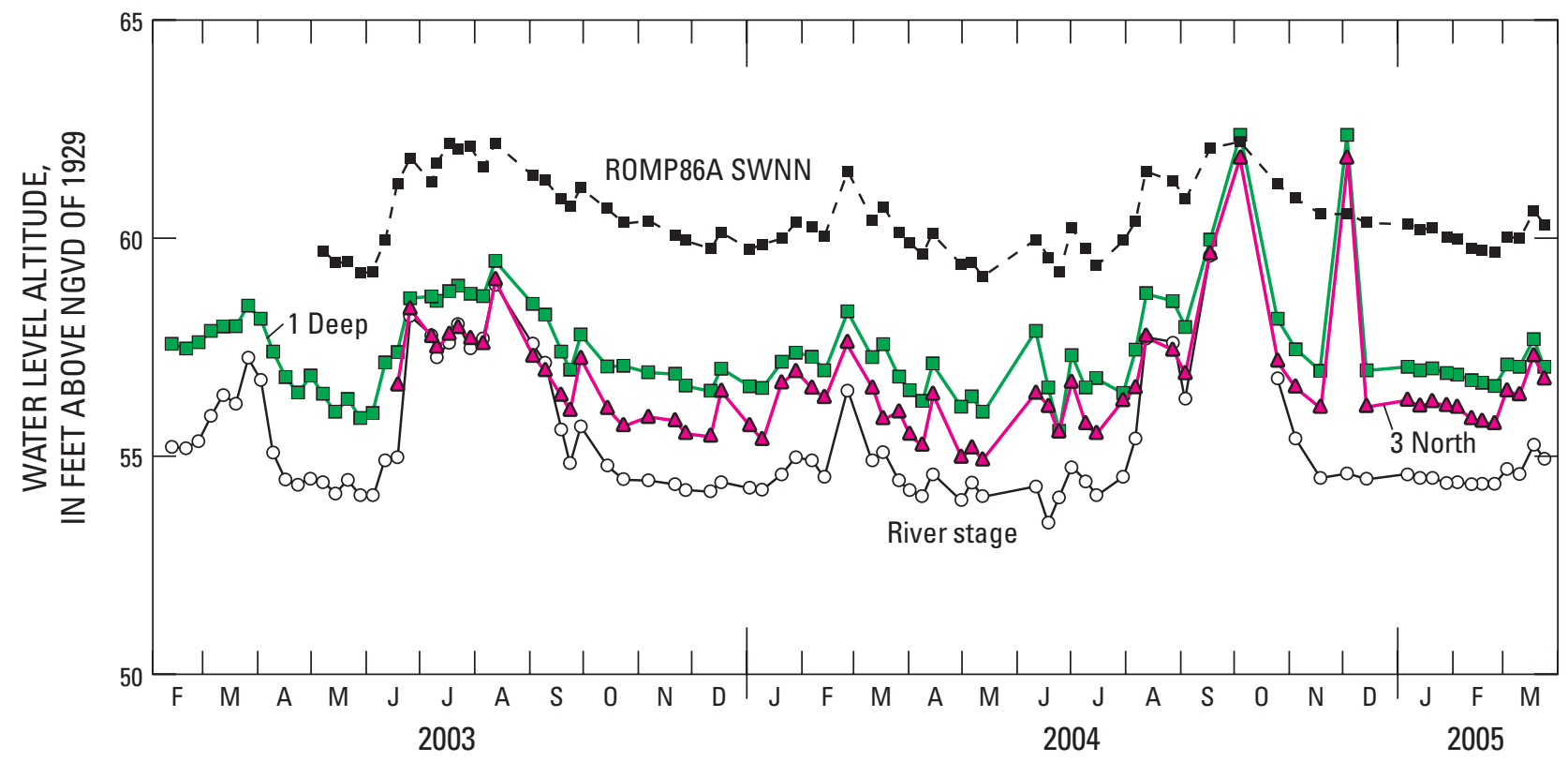

Figure 13. Weekly groundwater levels and river stage at the SR39 site (well locations shown in figure 4).

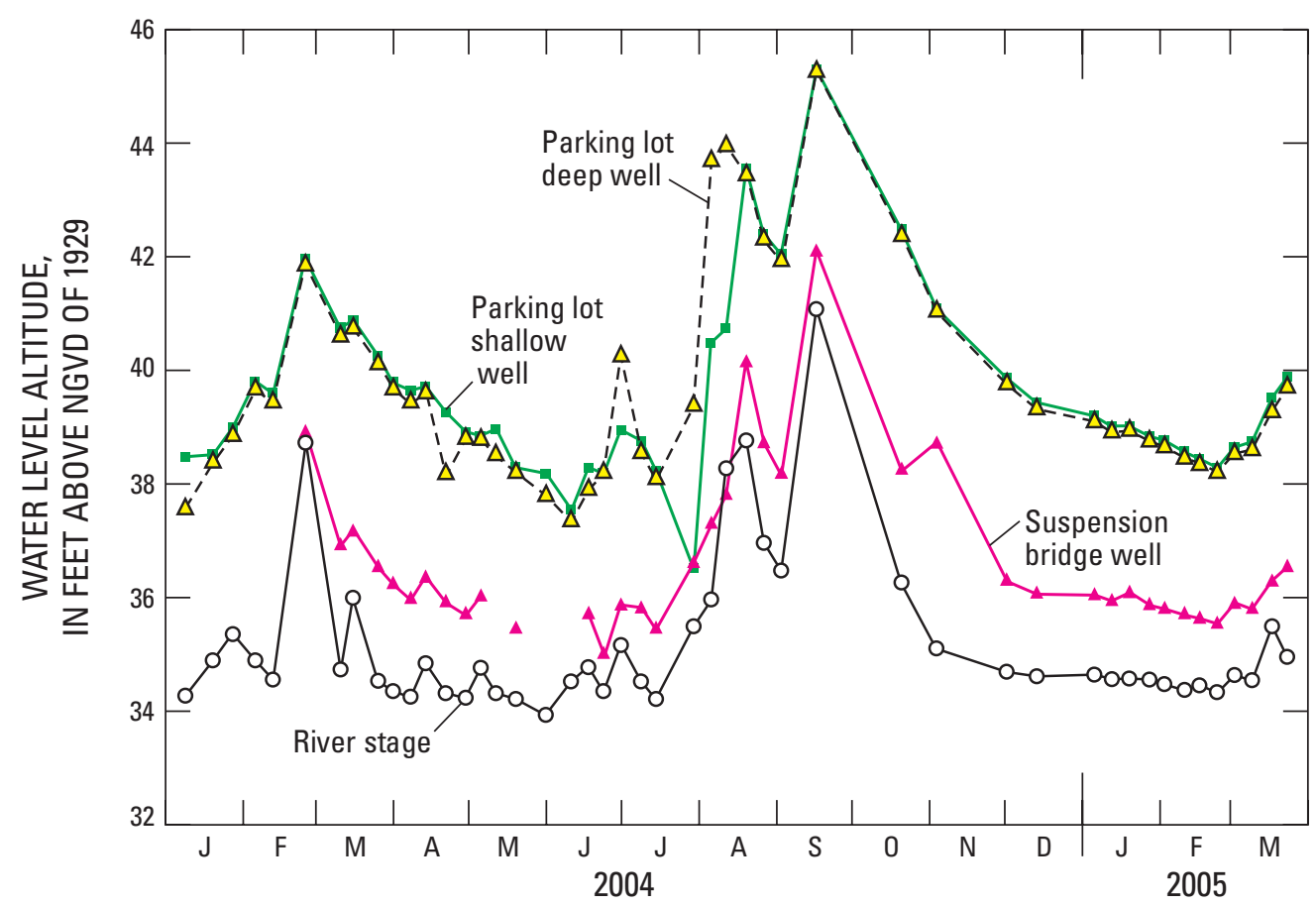

Figure 14. Weekly groundwater levels and river stage at the HRSP site (well locations shown in figure 5). 


\section{Water Quality}

The median concentrations of magnesium, potassium, chloride, bicarbonate plus carbonate, silica, dissolved organic carbon, and strontium in groundwater were similar between study sites, and all samples were calcium-bicarbonate water types (table 5). The Upper Floridan aquifer is close to land surface and the rock formation crops out in the stream channels in the upper part of the watershed. Because of localized karst features, the interconnection between the surficial aquifer and the Upper Floridan aquifer may be substantial (Trommer and others, 2007). The depth of wells completed in the Upper Floridan aquifer in this study ranged from 11.75 to $135 \mathrm{ft}$ below land surface.

Stiff diagrams were used to identify water types for precipitation, shallow and deep groundwater, and surface-water samples for the wet and dry seasons. Again, the surface water and groundwater samples collected at the SR39 and HRSP sites were calcium-bicarbonate water types, indicative of groundwater discharge through limestone. Hillsborough River samples collected at both sites during high- and low-flow periods resembled slightly diluted groundwater samples, indicating that most of the surface water originated from groundwater (figs. 15 and 16).

Although median concentrations of constituents in groundwater samples collected for this study did not vary widely, seasonal water-quality differences were present. Bar graphs for selected constituents are provided in figure 17 to illustrate the similarities and differences in the median concentrations of major ions. Water-quality samples from the Hillsborough River and groundwater at the SR39 and HRSP sites during the wet and dry seasons are compared in each of the bar graphs.

Median calcium concentrations in surface water were similar for the wet season at the SR39 site $(62.5 \mathrm{mg} / \mathrm{L})$, the dry season at the SR39 site $(66.3 \mathrm{mg} / \mathrm{L})$, and the dry season at the HRSP site $(60.3 \mathrm{mg} / \mathrm{L})$ (fig. 17A, table 5). The median calcium concentrations were substantially lower for the wet season at the HRSP site $(37.4 \mathrm{mg} / \mathrm{L})$. The median calcium concentrations of groundwater samples for the SR39 and HRSP sites were 90 and $116 \mathrm{mg} / \mathrm{L}$, respectively. Calcium and carbonate are the major constituents of limestone in the Upper Floridan aquifer, and these ions are dissolved in groundwater as it flows through, and interacts with, the rock matrix.

The median dissolved organic carbon (DOC) concentrations in surface water differed substantially between seasons, but were similar between sites; specifically, median DOC concentrations at the SR39 and HRSP sites were 6.6 and $4.2 \mathrm{mg} / \mathrm{L}$, respectively, during the dry season and 23.5 and $22.0 \mathrm{mg} / \mathrm{L}$, respectively, during the wet season (fig. 17B, table 5). The median concentrations of DOC in groundwater at the SR39 and HRSP sites were 2.2 and $2.3 \mathrm{mg} / \mathrm{L}$, respectively. During the wet season, DOC is released to surface waters when the channels and floodplains are hydraulically connected during high-flow periods.
Bar graphs for magnesium (fig. 17C) and strontium (fig. 17D) show that the median for each constituent was similar for surface-water and groundwater samples (approximately 2-5 mg/L for magnesium, and 100-300 $\mu \mathrm{g} / \mathrm{L}$ for strontium).

On March 19, 2003, groundwater samples collected from wells at the SR39 site also were analyzed for strontium and strontium isotopes. The strontium concentrations in the 1-Deep well and the 3-North well at the SR39 site were $816 \mu \mathrm{g} / \mathrm{L}$ and $181 \mu \mathrm{g} / \mathrm{L}$, respectively, whereas the median strontium concentration in the river at State Road 39 was $86 \mu \mathrm{g} / \mathrm{L}$ (fig. 18). The ${ }^{87} \mathrm{Sr} /{ }^{86} \mathrm{Sr}$ ratio in a water sample from the 1-Deep well was 0.70787 , which is within the range of values for Eocene-age seawater (Hess and others, 1986; Howarth and McArthur, 1997), and the ${ }^{87} \mathrm{Sr} /{ }^{86} \mathrm{Sr}$ ratio from the water sample from the 3-North well was 0.7080 , which is within the range of values for Oligocene-age seawater (fig. 19).

The ${ }^{2} \mathrm{H}$ and ${ }^{18} \mathrm{O}$ analyses for precipitation, groundwater, and surface-water samples were obtained at both sites throughout the study. Little difference was noted in the isotopic signature between rainfall and throughfall at either site, because both rainfall and throughfall isotopes plot near the local meteoric water line, as determined by Sacks (2002) (fig. 20). At both sites, ${ }^{2} \mathrm{H}$ and ${ }^{18} \mathrm{O}$ values for groundwater and surface water were offset to the right of the local meteoric water line. These samples plotted along the local evaporation trend line, described by Sacks (2002), indicating that groundwater and surface water were influenced by evaporation. The proximity of these samples to the local evaporation trend line suggests that these waters are composed of rainwater that has undergone some evaporation. The similar isotopic signatures of the groundwater and surface water further illustrate the prevalence of groundwater in the Hillsborough River, both during regular flows and throughout storm events.

Isotope samples from the HRSP site are closer to the meteoric water line than samples from the SR39 site. This difference indicates that water at the HRSP site had undergone less enrichment (that is, less evaporation) than water at the SR39 site. The discharge at SR39 is smaller and there is less tree cover over the river upstream from this site compared to the HRSP site, which may account for the greater evaporation at SR39.

\section{Geochemical Mass-Balance Methods for Base-Flow Separation}

The GMB and CMB methods for hydrograph separation were used to determine the contribution of base flow to total stormflow. The CMB method is a subset of a broader group of chemical mass balance methods. Input for the GMB method may include cations, anions, and stable isotopes, whereas input for the $\mathrm{CMB}$ method includes continuous or point samples of specific conductance. In this study, both GMB and $\mathrm{CMB}$ methods were used to estimate base flow. Field conditions limited the application of the GMB method to lowintensity storms, however, the CMB method was applied to low-intensity and high-intensity storms. 
Table 5. Summary of surface-water and groundwater quality for the Hillsborough River sites, 2003-2005.

[Locations of SR39 and HRSP sites are shown in figure 1. Constituents reported as milligrams per liter unless otherwise noted; Ca, calcium, Mg, magnesium; $\mathrm{Na}$, sodium; $\mathrm{K}$, potassium; $\mathrm{Cl}$, chloride; $\mathrm{SO}_{4}$, sulfate; Alk, alkalinity, as $\mathrm{CaCO}_{3}$; F, fluoride; $\mathrm{SiO}_{2}$, silica; $\mathrm{Br}$, bromide; DOC, dissolved organic carbon; $\mathrm{Sr}$, strontium, in micrograms per liter; Min, minimum; Max, maximum; N, number of samples; $<$, less than]

\begin{tabular}{|c|c|c|c|c|c|c|c|c|c|c|c|c|}
\hline $\begin{array}{c}\text { Con- } \\
\text { stituent }\end{array}$ & Median & Min & Max & $\mathbf{N}$ & $\begin{array}{c}\text { Lower } \\
\text { quartile }\end{array}$ & $\begin{array}{c}\text { Upper } \\
\text { quartile }\end{array}$ & Median & Min & Max & $\mathbf{N}$ & $\begin{array}{c}\text { Lower } \\
\text { quartile }\end{array}$ & $\begin{array}{c}\text { Upper } \\
\text { quartile }\end{array}$ \\
\hline \multicolumn{7}{|c|}{ Surface water at SR39 site, wet season } & \multicolumn{6}{|c|}{ Surface water at SR39 site, dry season } \\
\hline $\mathrm{Mg}$ & 3.85 & 1.7 & 4.40 & 68 & 3.55 & 4.1 & 4.29 & 2.47 & 5.52 & 63 & 3.90 & 4.46 \\
\hline $\mathrm{Na}$ & 6.5 & 3.6 & 7.2 & 68 & 6.175 & 6.9 & 7.50 & 5.15 & 9.00 & 63 & 7.27 & 7.75 \\
\hline $\mathrm{SO}_{4}$ & 16 & 2.3 & 20 & 67 & 14 & 19 & 12.60 & 2.77 & 20.00 & 63 & 9.60 & 15.46 \\
\hline Alk & 157 & 43 & 177 & 52 & 151 & 164 & 158 & 74 & 423 & 44 & 147 & 179.25 \\
\hline $\mathrm{F}$ & 0.2 & 0.2 & 0.2 & 3 & 0.2 & 0.2 & 0.20 & 0.19 & 0.22 & 5 & 0.20 & 0.20 \\
\hline $\mathrm{SiO}_{2}$ & 7.2 & 4.7 & 10 & 68 & 6.9 & 7.7 & 7.40 & 3.20 & 9.45 & 49 & 6.99 & 7.70 \\
\hline \multicolumn{7}{|c|}{ Surface water at HRSP site, wet season } & \multicolumn{6}{|c|}{ Surface water at HRSP site, dry season } \\
\hline $\mathrm{Ca}$ & 37.4 & 23 & 50 & 7 & 29.5 & 40.5 & 60.34 & 36.90 & 67.40 & 48 & 55.25 & 64.13 \\
\hline $\mathrm{Mg}$ & 3.5 & 2.4 & 4.5 & 7 & 2.985 & 4.15 & 4.70 & 3.30 & 6.70 & 48 & 4.50 & 4.83 \\
\hline $\mathrm{Na}$ & 7.9 & 5.2 & 16 & 7 & 6.99 & 10.75 & 11.88 & 5.40 & 23.72 & 48 & 9.98 & 12.81 \\
\hline $\mathrm{K}$ & 3.3 & 2.3 & 4.8 & 7 & 2.355 & 3.7 & 2.28 & 0.40 & 4.70 & 48 & 2.03 & 2.73 \\
\hline $\mathrm{Cl}$ & 11.3 & 9.2 & 20 & 7 & 10.3 & 16 & 17.56 & 10.00 & 32.68 & 46 & 16.00 & 19.00 \\
\hline $\mathrm{SO}_{4}$ & 16 & 4.7 & 26 & 7 & 5.64 & 17.5 & 15.35 & 6.71 & 32.84 & 46 & 14.00 & 17.15 \\
\hline Alk & 66.5 & 53 & 80 & 2 & 59.75 & 73.25 & 152 & 94 & 193 & 31 & 133 & 157 \\
\hline $\mathrm{F}$ & 0.3 & 0.2 & 0.3 & 5 & 0.26 & 0.3 & 0.16 & 0.10 & 0.20 & 6 & 0.12 & 0.20 \\
\hline $\mathrm{Ca}$ & 90.0 & 65.0 & 111 & 26 & 75.5 & 98.0 & 116 & 107 & 122 & 7 & 111 & 120 \\
\hline $\mathrm{Mg}$ & 2.20 & 2.00 & 9.50 & 26 & 2.10 & 2.49 & 1.80 & 1.30 & 2.00 & 7 & 1.75 & 1.91 \\
\hline $\mathrm{Na}$ & 7.60 & 4.70 & 10.7 & 26 & 6.98 & 8.25 & 4.50 & 1.1 & 5.79 & 7 & 3.45 & 5.47 \\
\hline $\mathrm{K}$ & 0.30 & 0.20 & 2.05 & 26 & 0.20 & 0.40 & 0.20 & 0.20 & 0.3 & 4 & 0.20 & 0.23 \\
\hline $\mathrm{Cl}$ & 13.0 & 0.30 & 19.0 & 26 & 8.23 & 14.0 & 9.30 & 0.2 & 11.8 & 7 & 5.30 & 10.8 \\
\hline $\mathrm{SO}_{4}$ & 2.60 & 0.26 & 23 & 26 & 0.85 & 12.8 & 5.50 & 3.30 & 6.20 & 5 & 4.90 & 5.70 \\
\hline Alk & 231 & 200 & 262 & 14 & 225 & 235 & 283 & 274 & 286 & 3 & 279 & 285 \\
\hline $\mathrm{F}$ & 0.12 & $<0.10$ & 0.20 & 12 & 0.10 & 0.18 & & & & & & \\
\hline $\mathrm{SiO}_{2}$ & 12 & 11 & 20 & 26 & 11.0 & 12.7 & 14.0 & 12.5 & 18.0 & 5 & 12.8 & 18.0 \\
\hline $\mathrm{Br}$ & 0.10 & 0.10 & 0.12 & 12 & 0.10 & 0.10 & & & & & & \\
\hline DOC & 2.2 & 1.5 & 6.2 & 26 & 2.00 & 2.85 & 2.30 & 1.40 & 6.40 & 7 & 1.95 & 5.80 \\
\hline $\mathrm{Sr}$ & 170 & 100 & 876 & 26 & 160 & 196 & 237 & 170 & 295 & 5 & 170 & 295 \\
\hline
\end{tabular}



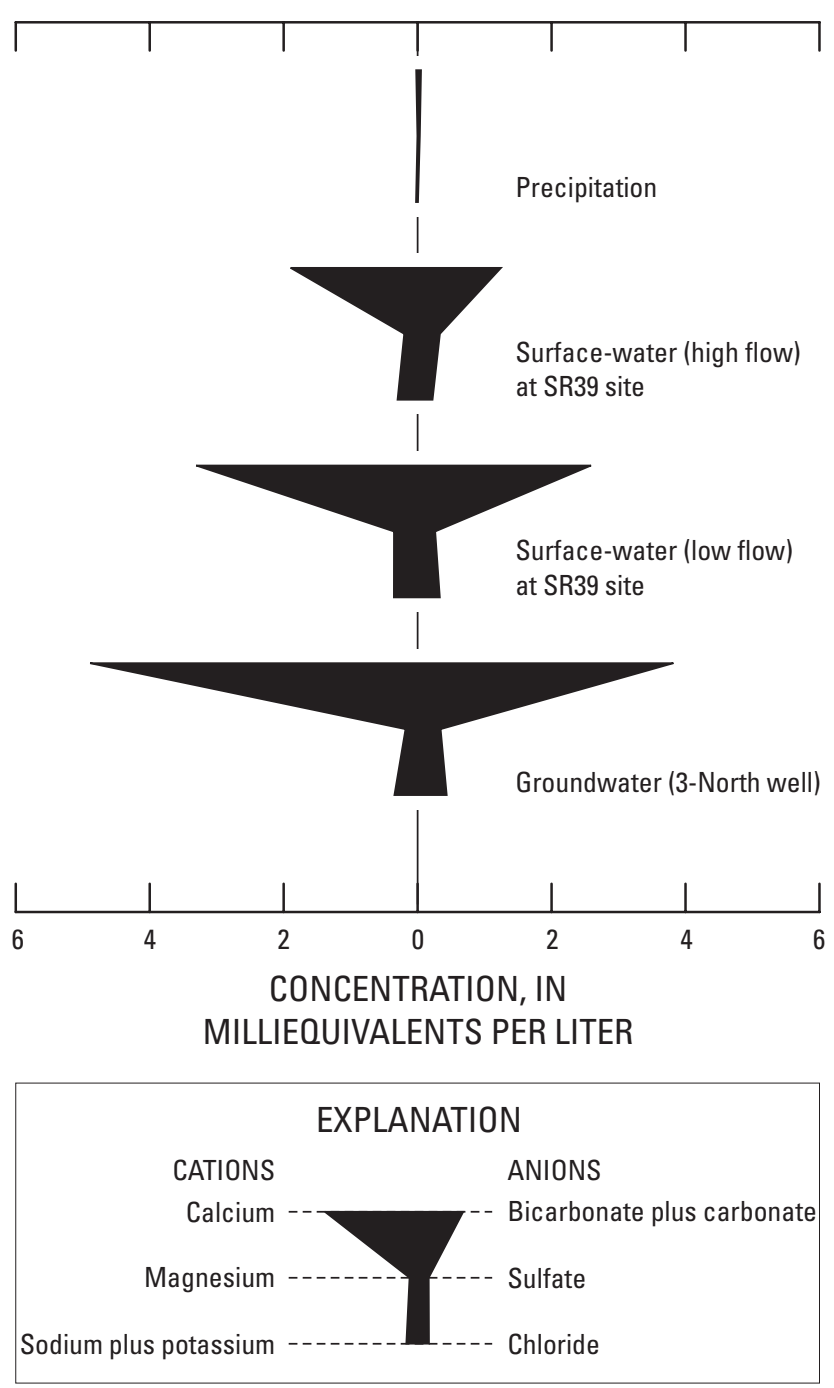

Figure 15. Stiff diagrams of geochemical analyses for precipitation, surface water, and groundwater at the SR39 site.
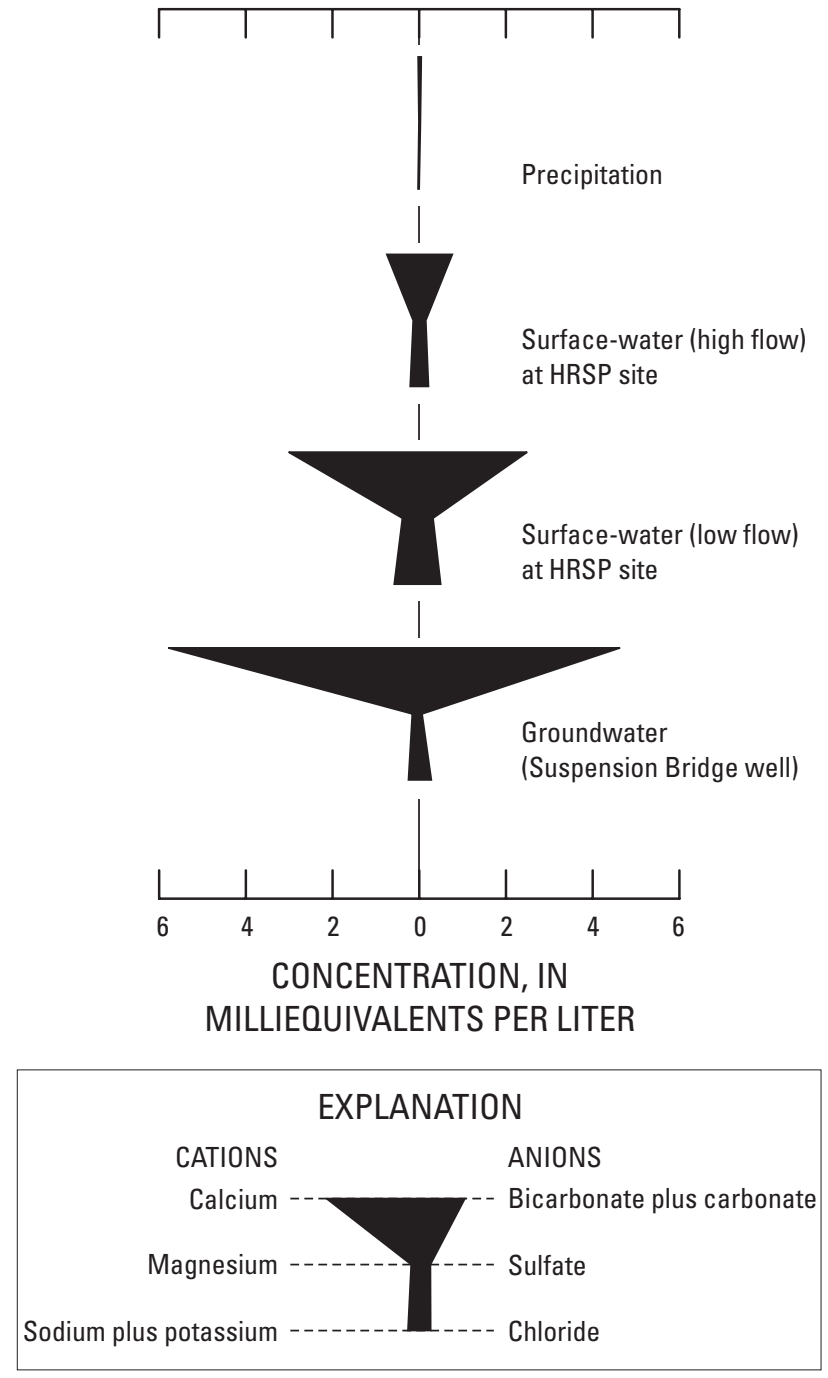

Figure 16. Stiff diagrams of geochemical analyses for precipitation, surface water, and groundwater at the HRSP site. 

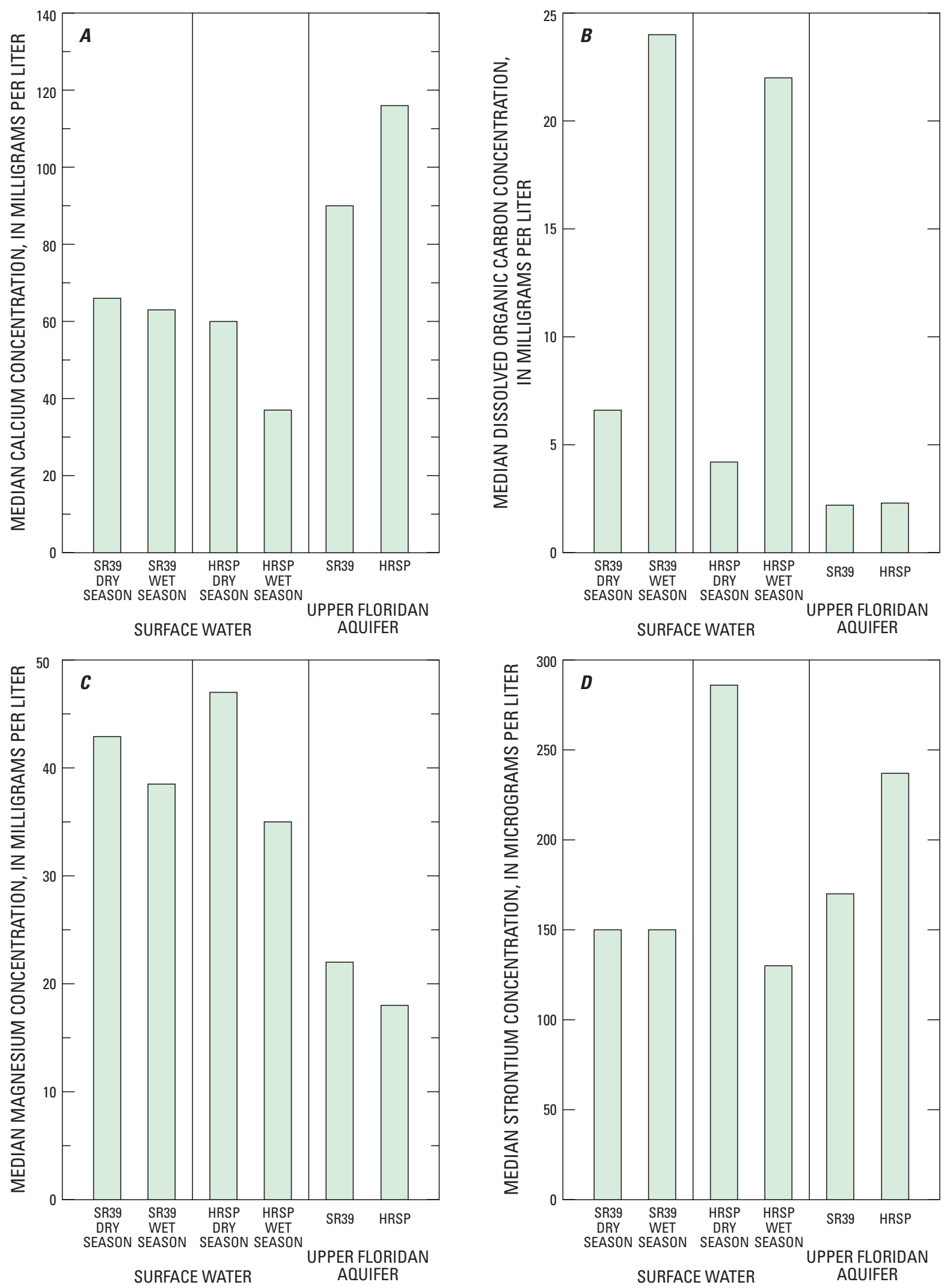

Figure 17. Selected median constituent concentrations in water at the SR39 and HRSP sites for dry and wet seasons, and for groundwater samples from Upper Floridan aquifer wells, 2003-2005 for $A$, calcium, $B$, dissolved organic matter, $C$, magnesium, and $D$, strontium. 


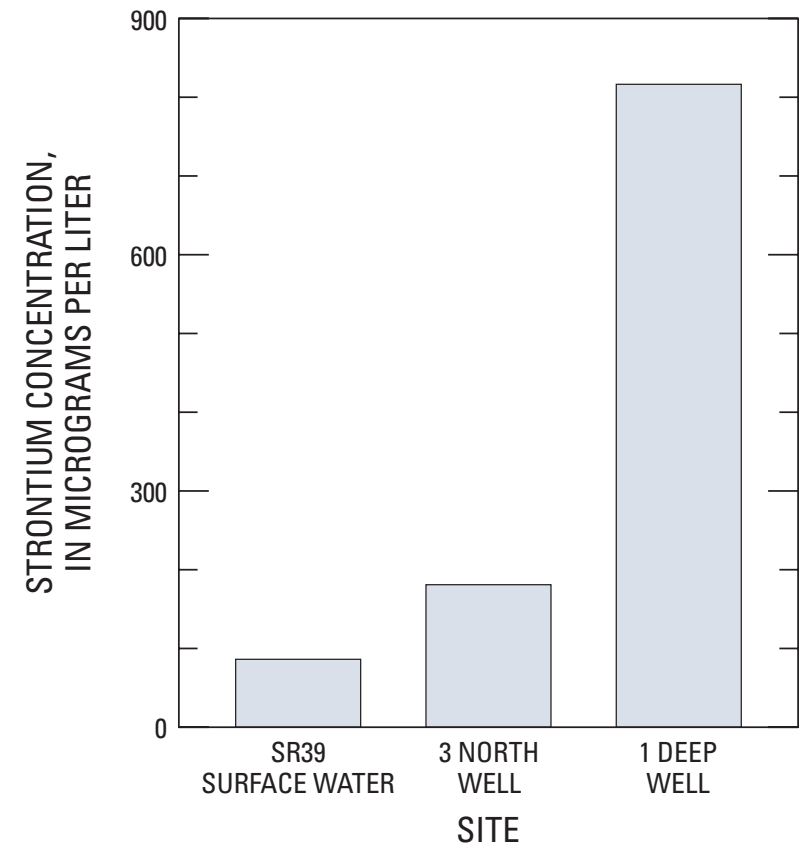

Figure 18. Strontium concentrations in surface water and the Upper Floridan aquifer at the SR39 site on March 19, 2003.

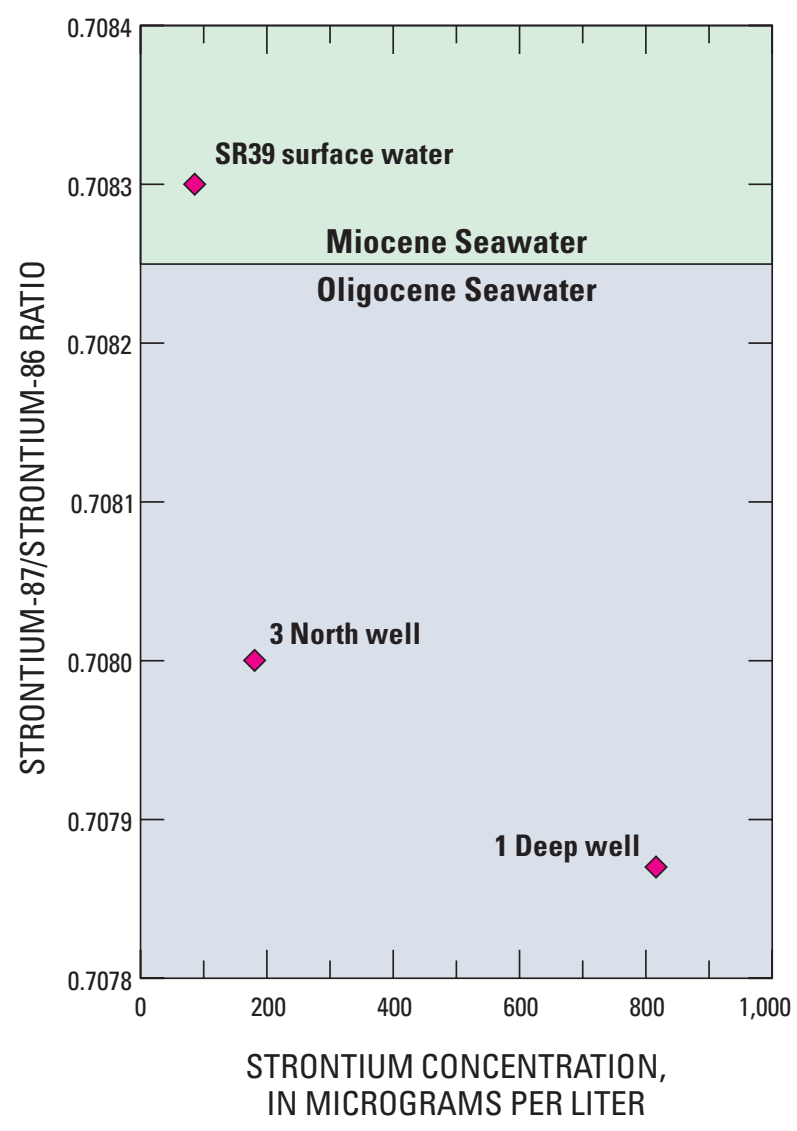

Figure 19. Relation between ${ }^{87} \mathrm{Sr} /{ }^{86} \mathrm{Sr}$ ratio and strontium concentrations in surface water and the Upper Floridan aquifer at the SR39 site on March 19, 2003 (seawater boundaries from Howarth and McArthur, 1997)
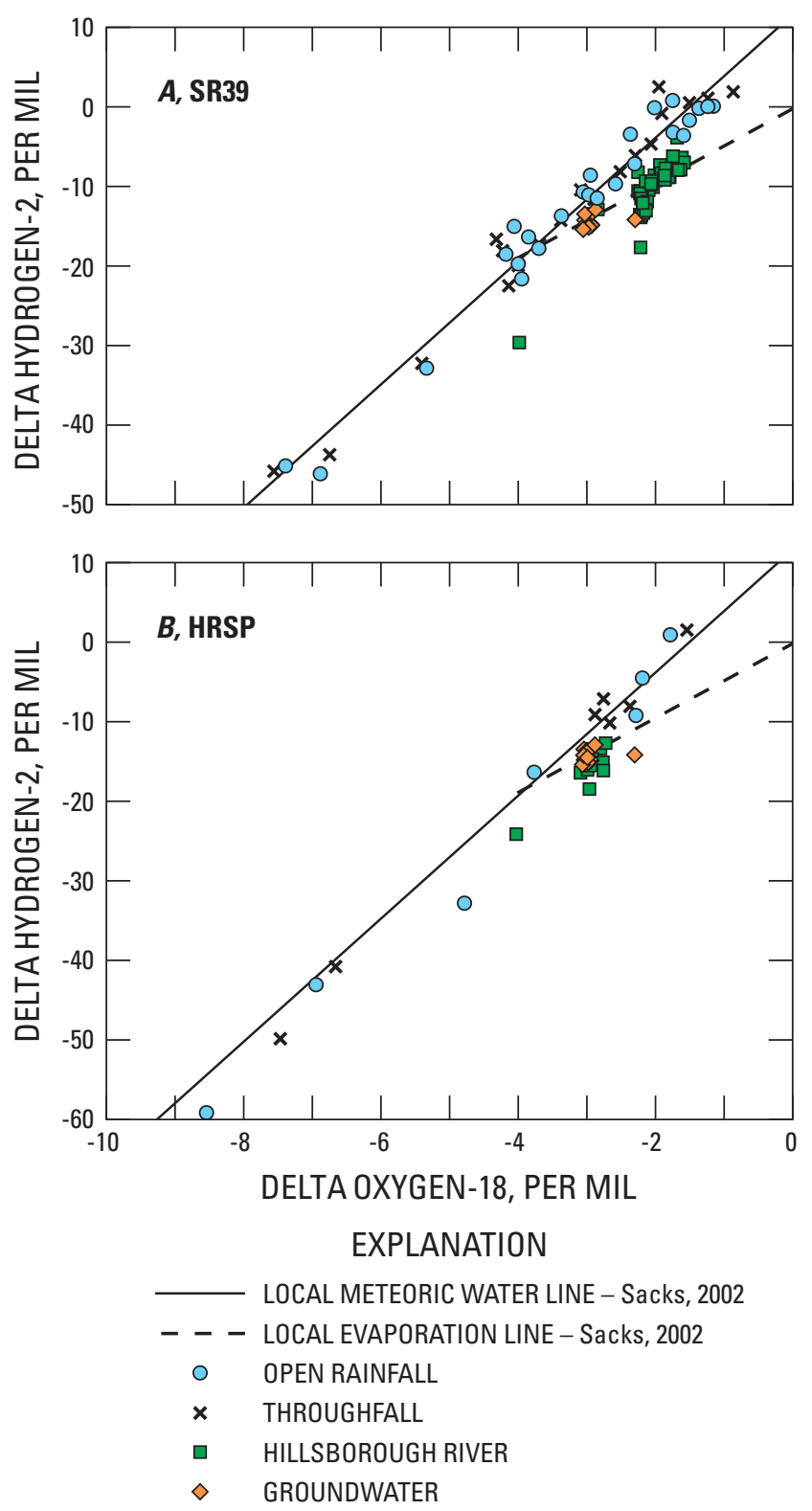

Figure 20. Relation between delta hydrogen-2 and oxygen-18 isotope concentrations in surface water at the $A$, SR39 site, and $B, \mathrm{HRSP}$ site, compared with local meteoric water for Florida. 
The CMB method described by Stewart and others (2007) is based upon four assumptions:

- Base-flow conductivity remains constant. Shortterm observations of conductivity remain relatively constant even when soil conditions change abruptly from very dry to saturated.

- Runoff conductivity remains constant. Although surface runoff conductivity increases from the groundwater divide to the stream with increased contact time with the soil, conductivity measurements from one storm event to the next at the same location yield consistent results. Regardless of whether or not a single storm event occurred after an extended dry period, or frequent runoff events occurred during the wet season, surface runoff conductivity remained relatively constant at a given location.

- Streamflow conductivity at lowest flows (pre-event flow) is used as an estimate of base-flow conductivity for the CMB method, because this value represents the weighted average conductivity of all base flow upstream from the measurement.

- Streamflow conductivity at highest flows is used as an estimate of runoff conductivity for the CMB method, because this value represents the weightedaverage conductivity of all surface runoff influx upstream from the measurement.

From these assumptions, Stewart and others (2007) provide a framework for applying the CMB method for annual estimates of base flow from mean daily data. The CMB method relies on measured values of stream conductivity during periods of very high flows and very low flows to estimate runoff and baseflow conductivity, respectively. It is reasonable to use lowflow values to estimate base-flow conductivity, as there is little or no surface runoff during extended periods of low flow.

If a short period of record of stream conductivity that does not include many high-flow events is used for calibrating the CMB method for an annual estimate of base flow, it is possible that a value of runoff conductivity will be selected that is higher than the actual long-term runoff conductivity. When this conductivity value is applied to a longer discharge record that does contains higher flows than the period for which specific conductance data are available, base-flow contributions may be underestimated. Similarly, if the stream conductivity does not reach a maximum (assumed to be 100 percent groundwater) before the next storm event, base-flow contributions may be overestimated. For this reason, short records of mean daily stream specific conductance data that do not contain substantial periods of high flows may not produce an accurate calibration when using the CMB method. Estimates of base flow when using the GMB method over the duration of individual storms may improve base-flow estimates by providing storm-specific base-flow estimates.
The GMB and CMB methods were applied to five storms at the SR39 site (September 2003, March 2004, AugustNovember 2004, January 2005, and February 2005), four storms at the HRSP site (July 2004, September-October 2004, January 2005, and February 2005), and one high-intensity storm at the HRSP site (September 2009). The CMB method alone was applied to high-intensity storms at the SR39 site (March 2003, August-November 2003) and the HRSP site (July 2004, August-November 2004, and September 2009) because geochemical data were unavailable.

The GMB and CMB methods use two end-members, concentration of pre-event flow (base flow) and concentration of peak discharge, to estimate the base-flow contribution to total discharge during storm events. The GMB/CMB results were determined from calcium and magnesium concentrations and specific conductance. Other cations, anions, and isotopes did not exhibit substantial enough differences between pre-event and/ or peak runoff so that they could be used as end members for the GMB method. Pre-event values and peak discharge values for selected constituents were determined for the period of study (table 6). These values were used in the GMB model to predict the percentage of stormflow attributable to pre-event flow for the peak flow and average flow of each storm event.

Base-flow discharge computed by the CMB/GMB methods from the storm data is expressed as a percentage of the measured discharge. The first storm sampling period at the SR39 site was from September 25 to September 28, 2003. Over this 3-day period, 0.74 in. of rainfall caused stream discharge to increase from 28 to $50 \mathrm{ft}^{3} / \mathrm{s}$ at the SR39 site (fig. 21). Table 7 shows the input to the model (measured values) and the calculated results (estimated base-flow end members) for the sampling point associated with the highest discharge during this storm. The model also calculated the $Q_{B F}$ (base-flow discharge estimated from specific conductance or constituent concentration) and $\%_{B F}$ (percentage of discharge attributed to base flow) determined by conductivity or geochemical mass balance methods for each sampling point during the course of the storm. Table 8 provides a summary of the percentage of peak and average discharge attributed to base flow for selected constituents and storm events.

Table 6. Pre-event and runoff end member values used in the geochemical mass balance method.

[Pre-event value assumed to be 100 percent base flow. Runoff value assumed to be 100 percent runoff; $\mu \mathrm{S} / \mathrm{cm}$ at $25^{\circ} \mathrm{C}$, microsiemens per centimeter at 25 degrees Celsius; mg/L, milligram per liter]

\begin{tabular}{llcc}
\hline \multicolumn{1}{c}{ Constituent } & \multicolumn{1}{c}{ Units } & Pre-event & Runoff \\
\hline $\begin{array}{l}\text { Specific } \\
\text { conductance }\end{array}$ & $\mu \mathrm{S} / \mathrm{cm}$ at $25^{\circ} \mathrm{C}$ & 350 & 100 \\
Calcium & $\mathrm{mg} / \mathrm{L}$ & 52.7 & 16.0 \\
Magnesium & $\mathrm{mg} / \mathrm{L}$ & 4.4 & 2.1 \\
\hline
\end{tabular}




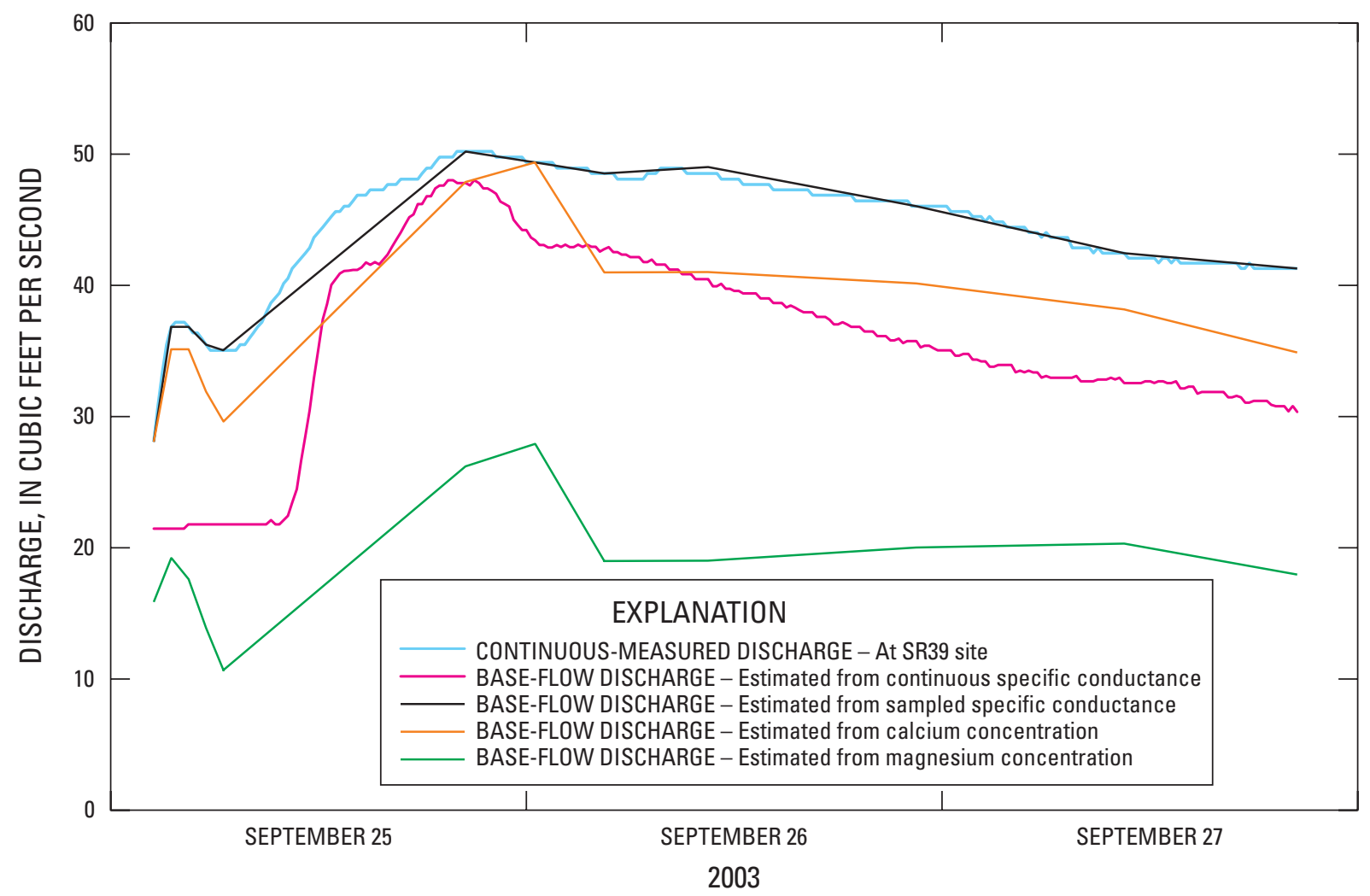

Figure 21. Observed storm hydrograph and discharges estimated by geochemical mass balance for selected major ions in SR39 surface water, September 2003 storm.

Table 7. Model input (measured) and model results (predicted) for the sampling point at the highest discharge using the geochemical mass balance method for the SR39 site during the low intensity storm event, September 25-28, 2003.

$\left[C_{\text {stream }}\right.$, measured concentration of calcium in surface water; $\mathrm{mg} / \mathrm{L}$, milligrams per liter; $C_{R O}$, predicted end member concentration of calcium in runoff discharge; $C_{B F}$, predicted end member concentration of calcium in surface water in base flow dicharge; $Q_{\text {stream }}$, stream discharge; $\mathrm{ft}^{3} / \mathrm{s}$, cubic feet per second; $Q_{B F}$, predicted base flow discharge; $\mathrm{ft}^{3} / \mathrm{s}$, cubic feet per second; Percent ${ }_{B F}$, predicted percentage of total stormflow discharge composed of base flow]

\begin{tabular}{ll}
\hline \multicolumn{1}{c}{ Parameter } & Value \\
\hline \multicolumn{1}{c}{ Model input } \\
\hline$C_{\text {Stream }}$ (measured) & $51 \mathrm{mg} / \mathrm{L}$ \\
$Q_{\text {Stream }}$ (measured) & $50 \mathrm{ft}^{3} / \mathrm{s}$ \\
\hline \multicolumn{2}{c}{ Model results } \\
\hline$Q_{B F}$ (predicted base flow) & $47 \mathrm{ft}^{3} / \mathrm{s}$ \\
Percent $_{B F}$ (predicted percent base flow) & $95 \%$ \\
$C_{R O}$ (estimated end member) & $16 \mathrm{mg} / \mathrm{L}$ \\
$C_{B F}$ (estimated end member) & $53 \mathrm{mg} / \mathrm{L}$ \\
\hline
\end{tabular}


Table 8. Percentage of peak and average discharge attributed to base flow determined by conductivity or geochemical mass balance methods for selected constituents and storm events.

[Location of SR39 and HRSP sites are shown in figure 1. CMB, conductivity mass balance method; GMB, geochemical mass balance method; nd, not determined; <, less than]

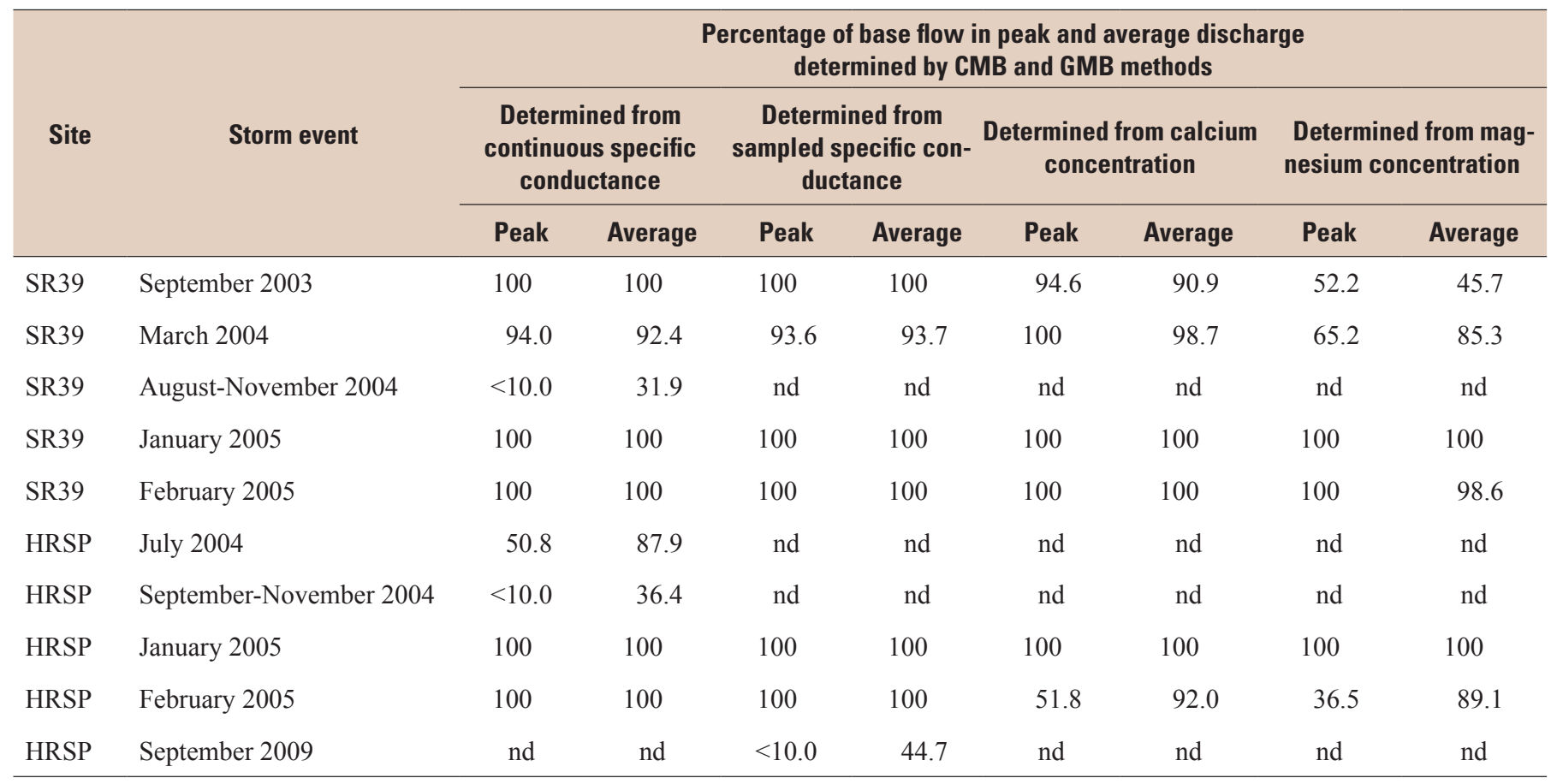

Using calcium as an example, the $Q_{B F}$ and $\%_{B F}$ for the September 2003 peak stormflow at the SR39 sites were solved for as follows:

$Q_{B F}=Q_{\text {stream }}\left[\frac{\left(C_{\text {stream }}-C_{R O}\right.}{C_{B F}-C_{R O}}\right]=50 \times\left[\frac{(51-16)}{(53-16)}\right]=47.3 \mathrm{ft}^{3} / \mathrm{s}$,

$$
\%_{B F}=\frac{Q_{B F}}{Q_{\text {stream }}} \times 100=\frac{47.3}{50} \times 100=94.6 \%
$$

Base-flow (pre-event) estimates based on sampled specific conductance, calcium concentration, magnesium concentration, and continuous specific conductance behaved similarly throughout the storm (fig. 21). Base flow at the SR39 site, estimated from sampled specific conductance and continuous specific conductance and expressed as a percentage of discharge, composed 100 percent of peak flow and 100 percent of average flow during the storm (table 8). Base flow estimated from calcium and magnesium concentrations was slightly and substantially lower, respectively, composing 95 and 52 percent for peak discharge and 91 and 46 percent of the average discharge during the storm.

The second storm sampling period at the SR39 site was from March 16 to March 23, 2004. Stream discharge ranged from 21 to $51 \mathrm{ft}^{3} / \mathrm{s}$ over this period, in response to $1.7 \mathrm{in}$. of precipitation. Base flow estimated from sampled specific conductance, continuous specific conductance, and calcium concentration, expressed as a percentage discharge, composed 94 to 100 percent of peak flow and 92 to 99 percent of average flow during the storm (fig. 22 and table 8). Base flow estimated from magnesium concentration was lower, composing 65 percent of peak discharge and 85 percent of average discharge during the storm.

The next storm sampling period at the SR39 site was from August to November 2004 during an active hurricane season. Discharge ranged from 20 to $1,459 \mathrm{ft}^{3} / \mathrm{s}$ over this 4-month period, and daily rainfall exceeded 2 in. on several days, causing periods of substantial stormwater-runoff. Base flow estimated from continuous specific conductance composed less than 10 percent of the peak flow during these runoff events and 32 percent of the average base flow during this period (fig. 23 and table 8). 


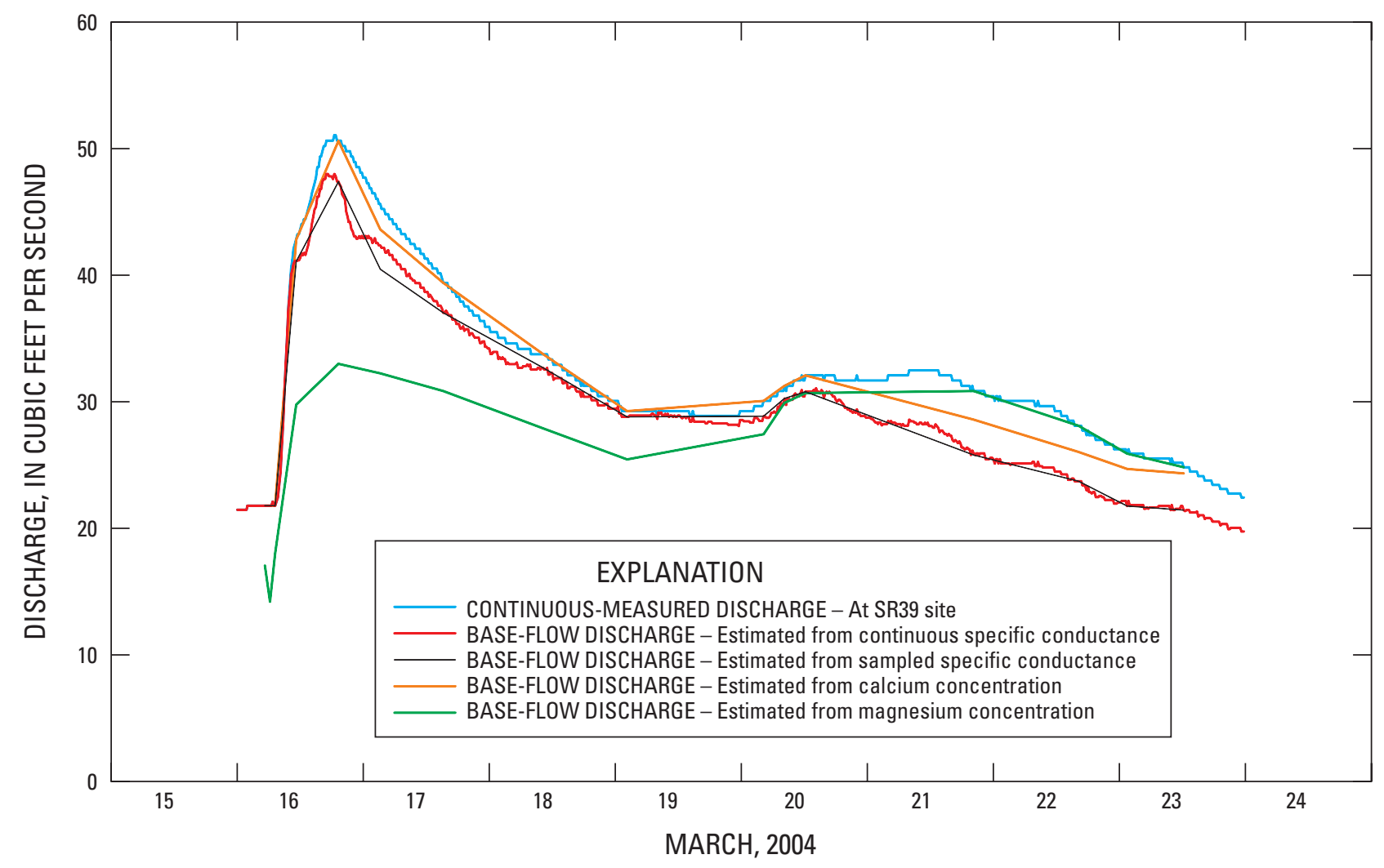

Figure 22. Observed storm hydrograph and discharges estimated by geochemical mass balance for selected major ions in SR39 surface water, March 2004 storm.

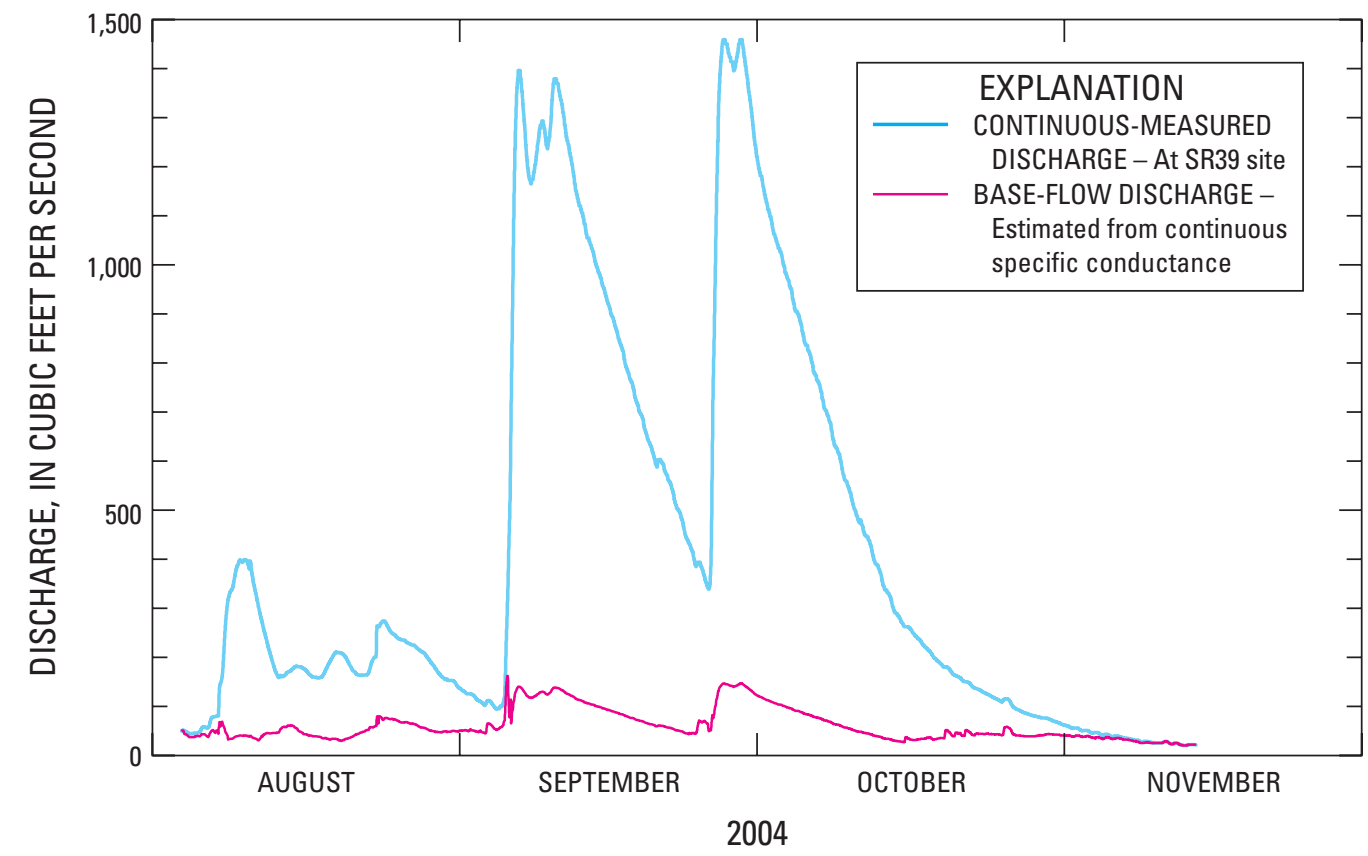

Figure 23. Observed storm hydrograph and discharges estimated by conductivity mass balance in SR39 surface water, August to November 2004. 


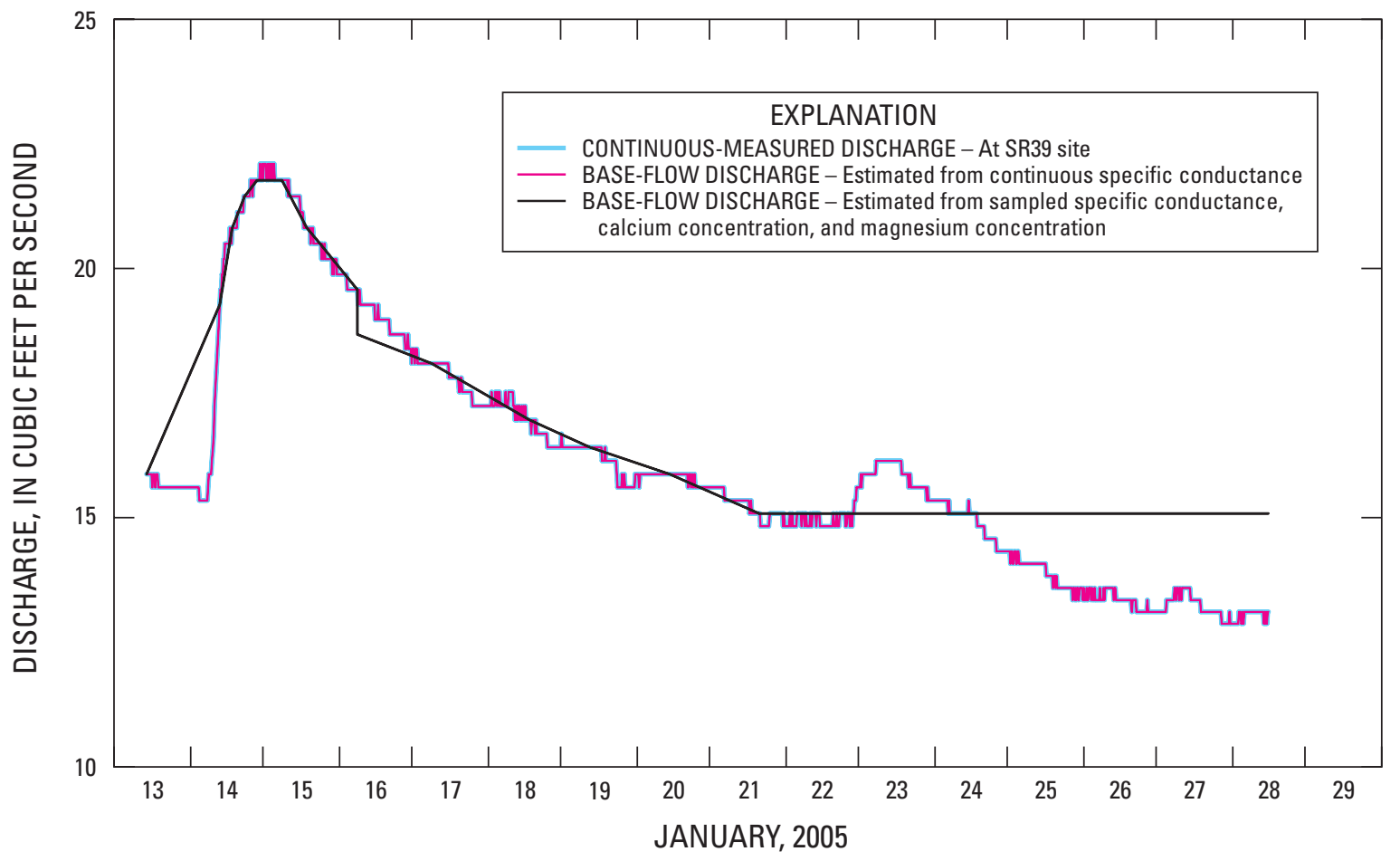

Figure 24. Observed storm hydrograph and discharges estimated by geochemical mass balance for selected major ions in SR39 surface water, January 2005 storm.

In January 2005, the SR39 site was sampled from January 13 to January 28 . The discharge ranged from 16 to $22 \mathrm{ft}^{3} / \mathrm{s}$, in response to 0.86 in. of precipitation. Base flow estimated from sampled specific conductance, continuous specific conductance, calcium concentration, and magnesium concentration was 100 percent of peak flow and 100 percent of average flow during the storm (fig. 24 and table 8).

During the storm event between February 24 and March 4, 2005, at the SR39 site, discharge increased from 12 to $38 \mathrm{ft}^{3} / \mathrm{s}$ in response to 2.13 in. of precipitation. Base flow estimated from sampled specific conductance, continuous specific conductance, and calcium concentration was 100 percent of peak flow and 100 percent of average flow during the storm (fig. 25 and table 8). Base flow estimated from magnesium concentration was 100 percent of peak discharge and 99 percent of average discharge during the storm.

At the HRSP site, the first stormflow lasted from July 16 to July 30,2004 . Stream discharge ranged from 83 to $551 \mathrm{ft}^{3} / \mathrm{s}$ over the 15-day period, in response to $13.8 \mathrm{in}$. of precipitation. Base flow estimated from continuous specific conductance was 51 percent of peak flow and 88 percent of average flow during the storm (fig. 26 and table 8).

The next storm sampling period at the HRSP site was from September to November 2004 during an active hurricane season. Discharge ranged from 188 to $6,410 \mathrm{ft}^{3} / \mathrm{s}$ over this period and peaked on September 7, 2004, after Hurricane Frances deposited 7 in. of precipitation. Several instances of daily rainfall exceeding $2 \mathrm{in}$. resulted in periods of substantial stormwater runoff events. Base flow estimated from continuous specific conductance was less than 10 percent of peak flow during three runoff events, and 36 percent of average discharge during this period (fig. 27 and table 8).

In January 2005, the HRSP site was sampled between January 13 to January 28 . The discharge ranged from 110 to $190 \mathrm{ft}^{3} / \mathrm{s}$ over this period in response to 0.8 in. of precipitation. Base flow estimated from continuous specific conductance was 100 percent of peak flow and 100 percent of average flow during the storm (fig. 28 and table 8). Base flow estimated from sampled specific conductance, calcium and magnesium concentrations, and sampled discharge was 100 percent of peak flow and 100 percent of average flow during the storm but the sampling frequency did not adequately represent the continuous storm hydrograph.

During a 9-day storm event between February 24 and March 4, 2005, discharge at the HRSP site increased from 81 to $162 \mathrm{ft}^{3} / \mathrm{s}$ in response to $2.08 \mathrm{in}$. of precipitation. Base flow estimated from sampled specific conductance and continuous specific conductance was 100 percent of peak flow and 100 percent of average flow during the storm. Base flow estimated from calcium was 52 percent of peak flow and 92 percent of average discharge during the storm (fig. 29 and table 8). Base flow estimated from magnesium concentration was 36 percent of peak flow and 89 percent of average discharge during the storm.

During the period from August 13 to September 9, 2009, discharge at the HRSP site ranged from 111 to $1,580 \mathrm{ft}^{3} / \mathrm{s}$, in response to 10.17 in. of precipitation. Base flow estimated from sampled specific conductance was less than 10 percent of peak flow and 45 percent of average flow during the storm (fig. 30 and table 8). 


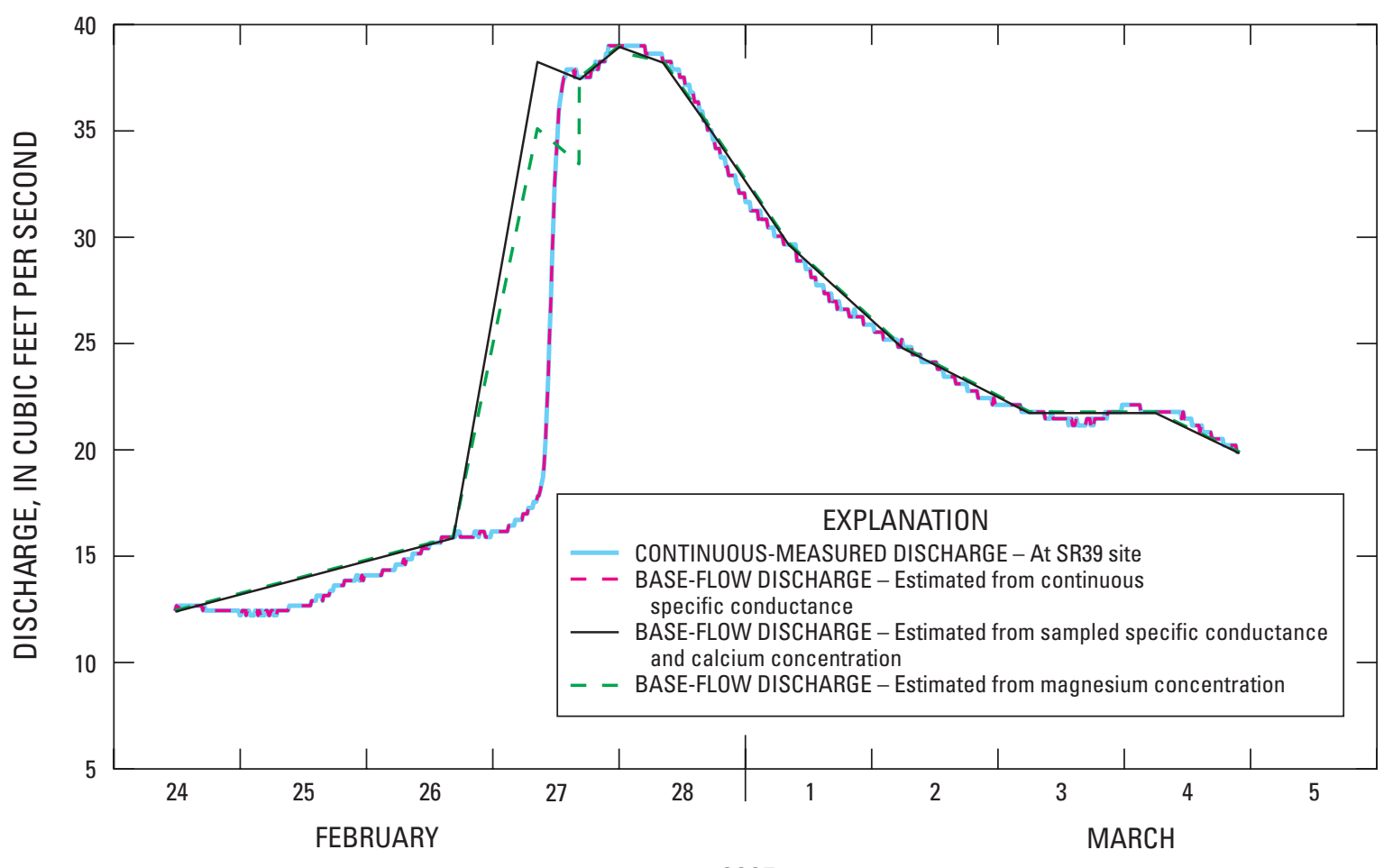

2005

Figure 25. Observed storm hydrograph and discharges estimated by geochemical mass balance for selected major ions in SR39 surface water, February/March 2005 storm.

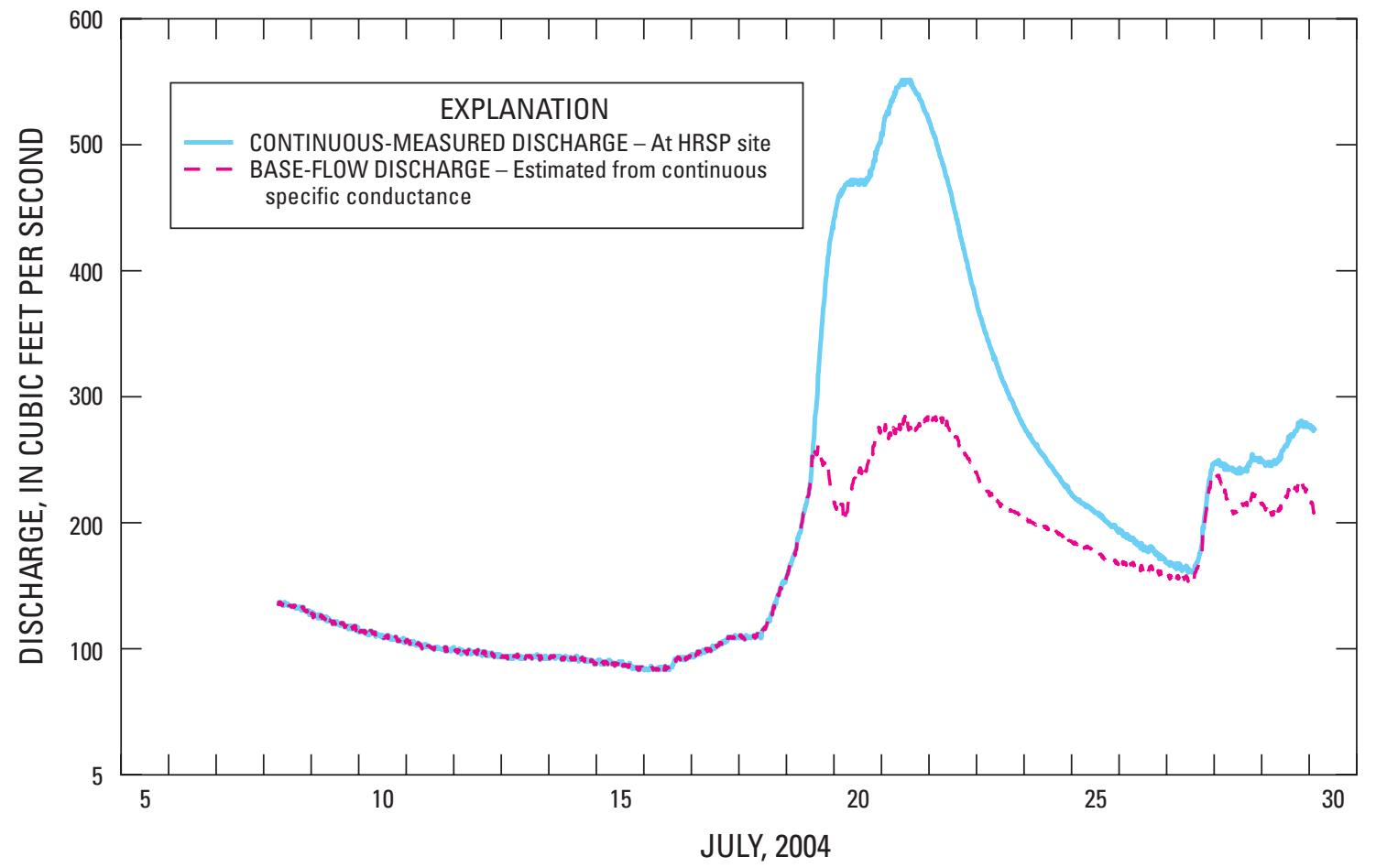

Figure 26. Observed storm hydrograph and discharges estimated by conductivity mass balance in HRSP surface water, July 2004. 


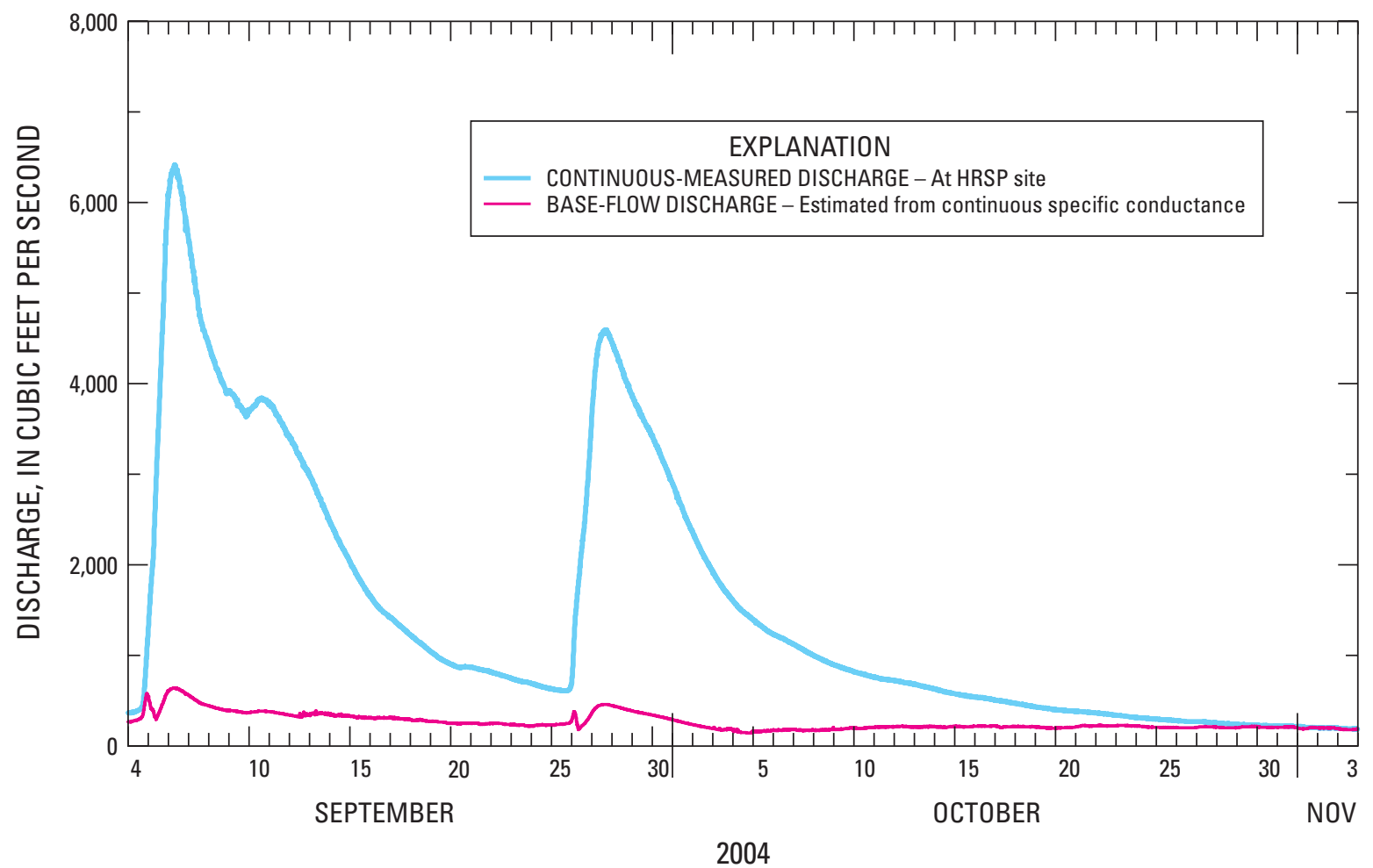

Figure 27. Observed storm hydrograph and discharges estimated by conductivity mass balance in HRSP surface water, September to November 2004.

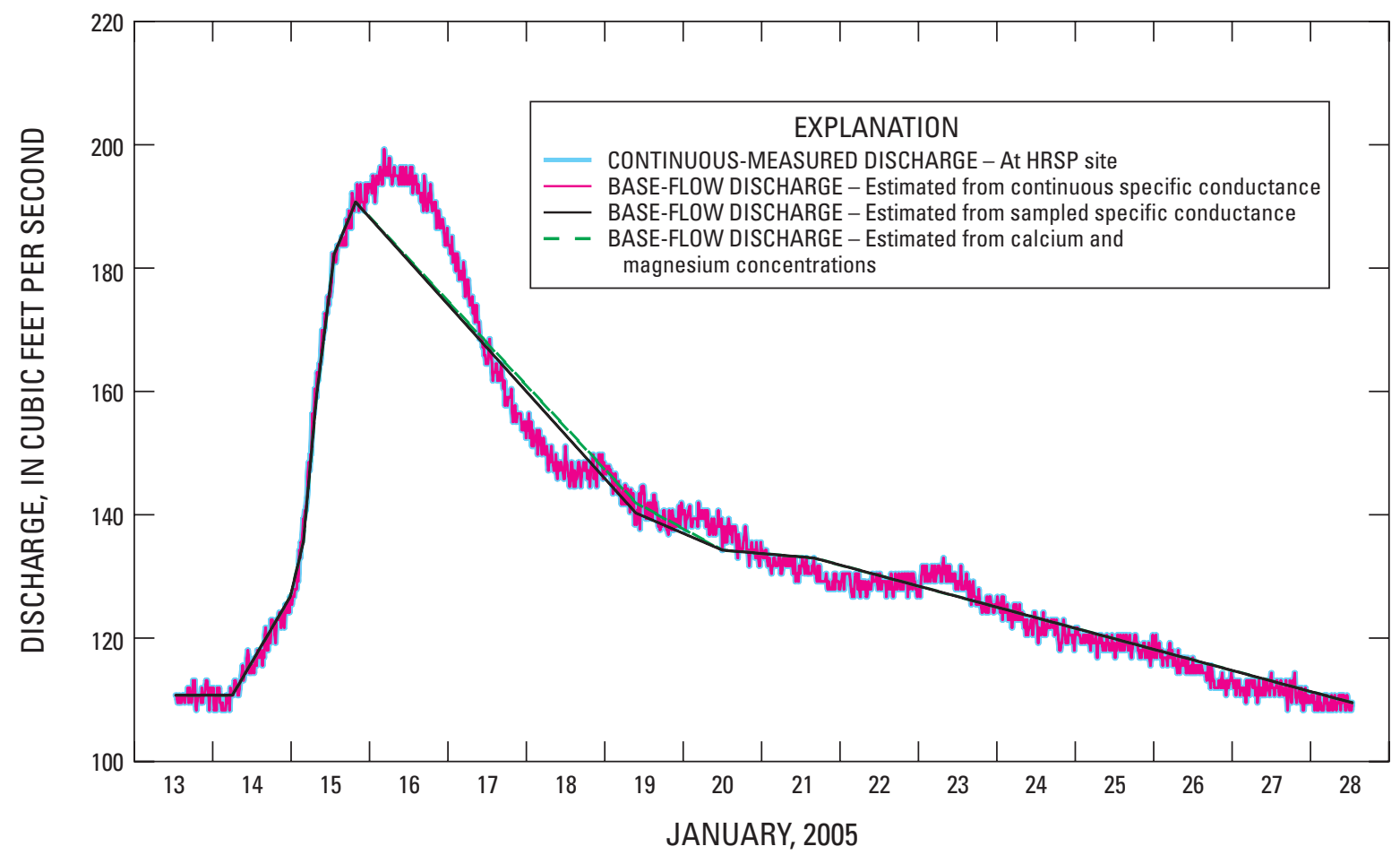

Figure 28. Observed storm hydrograph and discharges estimated by geochemical mass balance for selected major ions in HRSP surface water, January 2005 storm. 


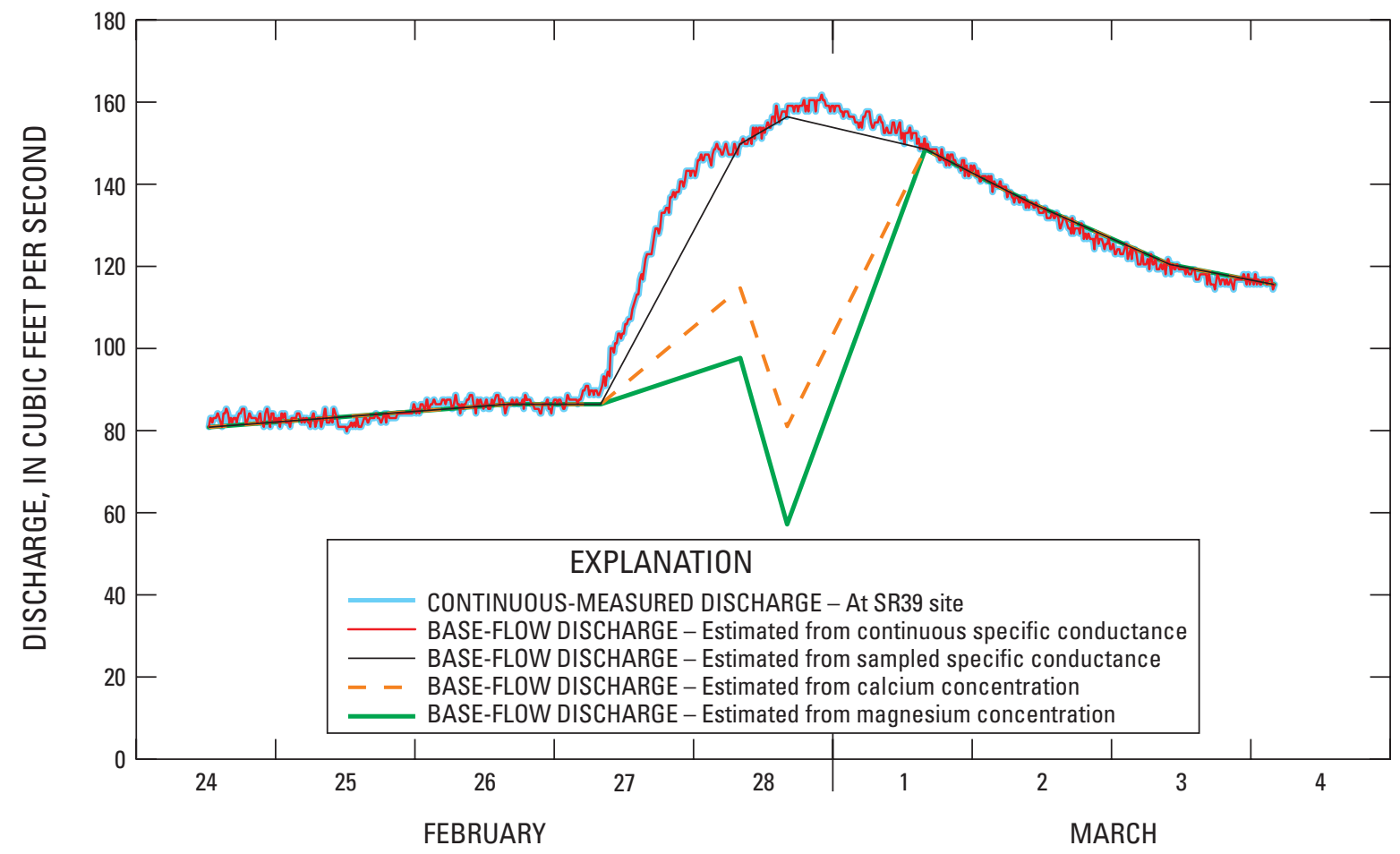

2005

Figure 29. Observed storm hydrograph and discharges estimated by geochemical mass balance for selected major ions in HRSP surface water, February/March 2005 storm.

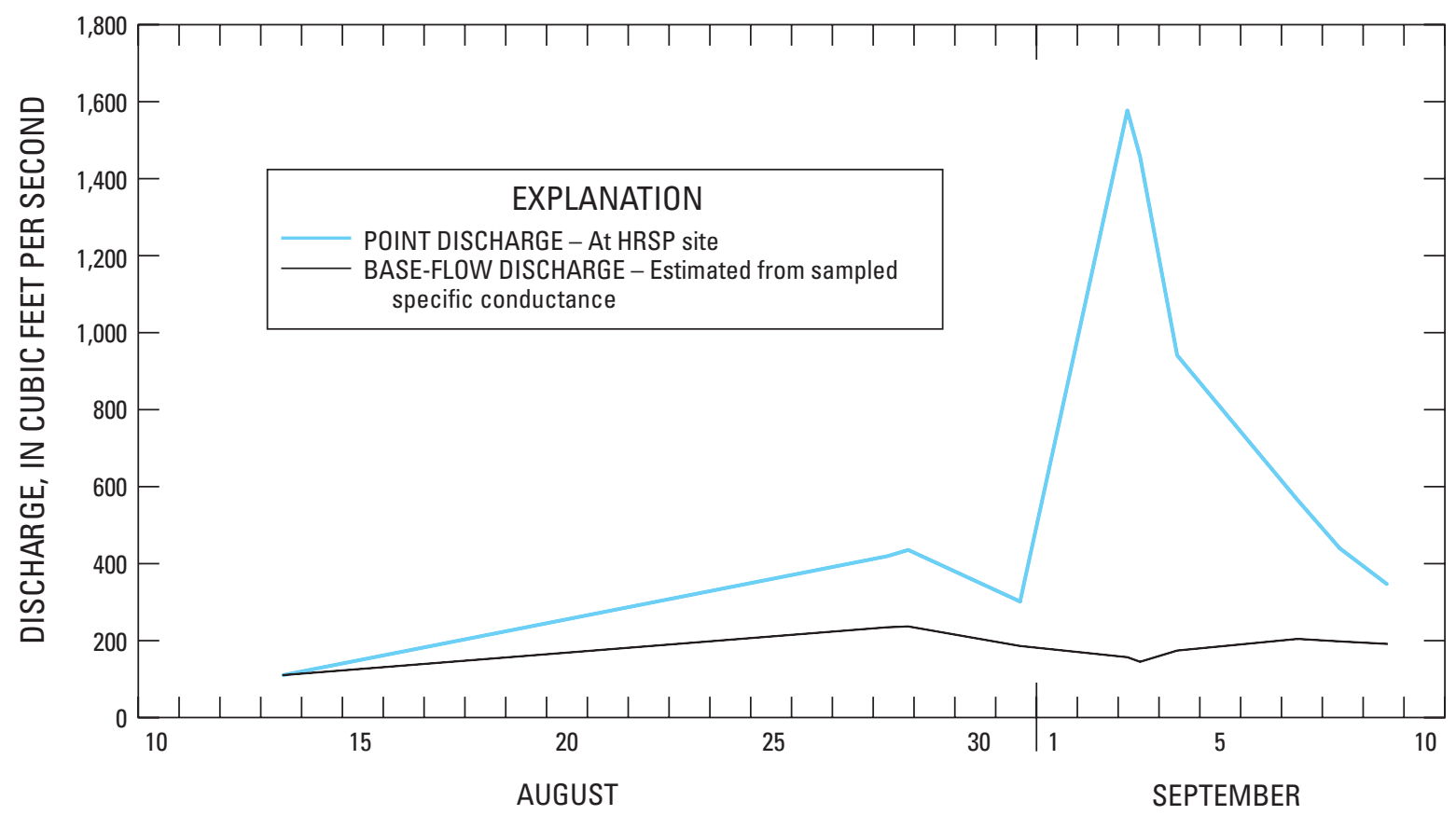

2009

Figure 30. Observed storm hydrograph and discharges estimated by conductivity mass balance in HRSP surface water, August and September 2009. 
Calcium, magnesium, and silica were used as end members for the GMB method, but their use in calculating base flow by the GMB method was limited because the frequency of samples was not sufficient to capture the complete hydrograph from pre-event flow to post-event base-flow concentrations. Hydrograph recession curves that are typical of hydrologic conditions in Florida often did not reach a minimum before the next storm event, and pre-event base-flow constituent concentrations represented a mixture of runoff and base flow.

The contribution of base flow to total discharge for all storms at both sites ranged from 31 to 100 percent, whereas the contribution of base flow to total discharge during peak discharge ranged from less than 10 to 100 percent (table 8). Pre-event base-flow constituent concentrations were lower than the peak runoff constituent concentrations for four storm events at the SR39 site (September 2003, March 2004, January 2005, and February 2005) and for two storm events at the HRSP site (January 2005 and February 2005). The model assumption that the pre-event base-flow concentrations are greater than peak runoff concentration was violated for these storm events. This may suggest that during these smaller storm events, the ratio of groundwater to runoff increased, so that peak flow had higher concentrations than pre-event flow.

\section{Summary}

The CMB and GMB methods were used to estimate the contribution of base flow to discharge in the upper part of the Hillsborough River watershed. Input for the GMB method included cations, anions, and stable isotopes, whereas input for the CMB method included continuous or point samples of specific conductance.

The chemical and isotopic composition of streamflow and precipitation was measured during selected local and frontal storm events and compared to the chemical and isotopic composition of groundwater. Daily and weekly precipitation at two sites in the upper Hillsborough River watershed, one a subbasin of the other, followed similar patterns, and surface-water and groundwater hydrographs mimicked the precipitation patterns.

Surface water in the watershed study area is a calciumbicarbonate type that closely resembles groundwater geochemically, indicating that much of the surface water in the upper Hillsborough River basin is derived from local discharge of groundwater. Discharge at the SR39 site and at the HRSP site becomes diluted by precipitation and runoff during the wet season, but retains the calcium-bicarbonate characteristic of Upper Floridan aquifer water. The ${ }^{2} \mathrm{H}$ and ${ }^{18} \mathrm{O}$ isotopes at both sites also were similar for groundwater and surface water, indicating groundwater was the principal source of streamflow.

Field conditions limited the application of the GMB method to low-intensity storms, but the CMB method was applied to both low-intensity and high-intensity storms. The average contribution of base flow to total discharge for all storms ranged from 31 to 100 percent, whereas the contribution of base flow to total discharge during peak discharge ranged from less than 10 percent to 100 percent.

Calcium, magnesium, and silica are consistent markers of Upper Floridan aquifer chemistry, but their use in calculating base flow by the GMB method was limited because the frequency of the point data collected in this study was not sufficient to capture the complete hydrograph from pre-event base flow to post-event base-flow concentrations. In this study, pre-event water represents somewhat diluted groundwater.

Streamflow conductivity integrates the concentrations of the major ions, and the logistics of acquiring specific conductance at frequent time intervals are less complicated than data collection, sample processing, shipment, and analysis of water samples in a laboratory. The acquisition of continuous specific conductance data reduces uncertainty associated with less frequently collected geochemical point data.

Total discharge at the upper Hillsborough River sites during low-intensity storm events consisted primarily of base flow. During high-intensity storms, total discharge was substantially diluted with runoff water so that less than 10 percent of the total discharge originated from groundwater.

\section{References Cited}

Bullen, T.D., and Kendall, C., 1998, Tracing of weathering reactions and water flowpaths: A multi-isotope approach, in Kendall, C., and McDonnell, C.C., eds., Isotope Tracers in Catchment Hydrology: Amsterdam, Elsevier Science, p. 610-646.

Buttle, J.M., 1994, Isotope hydrograph separations and rapiddelivery of pre-event water from drainage basins: Progress in Physical Geography, v. 18, no. 1, p. 16-41.

Cey, E.E., Rudolph, D.L., Parkin, G.W., and Aravena, R., 1998, Quantifying groundwater discharge to a small perennial stream in southern Ontario, Canada: Journal of Hydrology, v. 210, no. 1, p. 21-37.

Champion, K.M., and DeWitt, D.J., 2000, Origin of nitrate in ground water discharging from Crystal Springs, Pasco County, Florida: Brooksville, Southwest Florida Water Management District, 192 p.

Clesceri, L.S., Greenberg, A.E., and Eaton, A.D., eds., 1999, Standard methods for the examination of water and wastewater (20th ed.): American Public Health Association, American Water Works Association, and the Water Environment Federation, 1220 p.

Craig, H., 1961, Isotopic variations in meteoric waters: Science, v. 133, p. 1702-1703.

Epstein, S., and Mayeda, T.K., 1953, Variations of the ${ }^{18} \mathrm{O} /{ }^{16} \mathrm{O}$ ratio in natural water: Geochimica Cosmochimica Acta, v. 4, p. 213-224. 
Florida Administrative Code, 2000, Chapter 40D-8, Water levels and rates of flow: Accessed October 22, 2009, at: http:// www.swfwmd.state.fl.us/rules/files/40d-8.pdf.

Ford, D., and Williams, P., 1989, Karst geomorphology and hydrology: London, Unwin Hyman, 480 p.

Fritz, P., Cherry, J., Weyer, K.U., and Sklash, M., 1976, Storm runoff analyses using environmental isotopes and major ions, in Workshop Proceedings Interpretation of Environmental Isotope Hydrochemical Data in Ground Water Hydrology: Vienna, p. 111-130.

Gebert, W.A., Radloff, M.J., Considine, E.J., and Kennedy, J.L., 2007, Use of streamflow data to estimate base flow/ ground-water recharge for Wisconsin: Journal of the American Water Resources Association, v. 143, no. 1, p. 220-236.

Gonfiantini, Roberto, 1978, Standards for stable isotope measurements in natural compounds: Nature, v. 271, no. 5645 , p. 534-536.

Gremillion, P., and Wanielista, M., 2000, Effects of evaporative enrichment on the stable isotope hydrology of a central Florida (USA) river: Hydrological Processes, v. 14, p. 14651484.

Halford, K.J., and Mayer, G.C., 2000, Problems associated with estimating ground water discharge and recharge from stream-discharge records: Ground Water, v. 38, no. 3, p. 331-342.

Hall, F.R., 1968, Base flow recession, a review: Water Resources Research, v. 4, no. 5, p. 973-983.

Hess, J., Bender, M.L., and Schilling, J.G., 1986, Seawater ${ }^{87} \mathrm{Sr} /{ }^{86} \mathrm{Sr}$ evolution from Cretaceous to present: Science, v. 231, p. 979-984.

Hooper, R.P., and Shoemaker. C.A., 1986, A comparison of chemical and isotopic tracers: Water Resources Research, v. 22 , no. 10 , p. 1444-1454.

Howarth, R.J., and McArthur, J.M., 1997, Statistics for strontium isotope stratigraphy: A robust LOWESS fit to the marine Sr-isotope curve for 0-206 Ma, with look-up table for the derivation of numerical age: Journal of Geology, v. 105 , p. 441-456.

Institute of Hydrology, 1980, Low flow studies: Wallingford, Oxon, U.K., Report no. 3: p. 12-19.

Kendall, Carol, and McDonnell, J.J., 1998, Isotope tracers in catchment hydrology: Amsterdam, Elsevier Science, 870 p.

Lewelling, B.R., 2004, Extent of areal inundation of riverine wetlands along five river systems in the upper Hillsborough river watershed, west-central Florida: U.S. Geological Survey Scientific-Investigations Report 2004-5133, 49 p.
Lin, Kairong, Shenglian, Guo, Zhang, Wenhua, and Liu, Pan, 2007, A new baseflow separation method based on analytical solutions of the Horton infiltration capacity curve: Hydrological Processes, v. 21, p. 1719-1736.

Linsley, R.K., Kohler, M.A., and Paulhus, J.L., 1949, Applied hydrology: New York, McGraw-Hill, 654 p.

Metz, P. A. and Sacks, L.A., 2002, Comparison of the hydrogeology and water quality of a ground-water augmented lake with two non-augmented lakes in northwest Hillsborough County, Florida: U.S. Geological Survey WaterResources Investigation Report 2002-4032, 74 p.

Meyboom, P., 1961, Estimating ground-water recharge from stream hydrographs: Journal of Geophysical Research, v. 66 , no. 4 , p. $203-1214$.

Nathan, R.J., and McMahon, T.A., 1990, Evaluation of automated techniques for base flow and recession analyses: Water Resources Research, v. 26, no. 7, p. 1465-1473.

Pettyjohn, W.A., and Henning, R., 1979, Preliminary estimated ground water recharge rates, related stream flow, and water quality in Ohio: Water Resources Center Project Report 552, Columbus: Ohio State University.

Pinder, G.F., and Jones, J.F., 1969, Determination of the groundwater component of peak discharge from chemistry of total runoff: Water Resources Research, v. 5, p. 438-445.

Rantz, S.E., and others, 1982, Measurement and computation of streamflow: Vol. 2. Computation of discharge: U.S. Geological Survey Water-Supply Paper 2175, p. 285-631.

Revesz, Kinga, and Coplen, T.B., 2006, eds., Methods of the Reston Stable Isotope Laboratory: U.S. Geological Survey Techniques and Methods Report 10, variously paged.

Rice, K.C., and Hornberger, G.M., 1998, Comparison of hydrochemical tracers to estimate source contributions to peak flow in a small, forested, headwater catchment: Water Resources Research, v. 34, no. 7, p. 1755-1766.

Rorabaugh, M.I., 1964, Estimating changes in bank storage and ground water contribution to stream flow: International Association of Scientific Hydrology, Publication 63 p. 432-441.

Ross, M.P., Tara, P., Guerink, J., and Stewart, M., 1997, FIPR Hydrologic Model: User's manual and technical documentation, Tampa, Center for Modeling Hydrologic Systems, University of South Florida.

Rutledge, A.T., 1993, Computer programs for describing the recession of ground-water discharge and for estimating mean ground-water recharge and discharge from streamflow records: U.S. Geological Survey Water-Resources Investigations Report 93-4121, 45 p. 
Sacks, L.A., 2002, Estimating ground-water inflow to lakes in central Florida using the isotope mass-balance approach: U.S. Geological Survey Water-Resources Investigations Report 02-4192, 47 p.

Scanlon, T.M., Raffensperger, J.P., and Hornberger, G.M., 2001, Modeling transport of dissolved silica in a forested headwater catchment: Implications for defining the hydrochemical response of observed flow pathways: Water Resources Research, v. 37, no. 4, p. 1071-1082.

Searcy, J.C., 1959, Flow duration curves: U.S. Geological Survey Water-Supply Paper 1542A, 33 p.

Sinclair, W.C., 1974, Hydrologic characteristics of the surficial aquifer in northwest Hillsborough County, Florida: Tallahassee, Florida Bureau of Geology, Information Circular 86, $98 \mathrm{p}$.

Sloto, R.A., and Crouse, M.Y., 1996, HYSEP: A computer program for streamflow hydrograph separation and analysis: U.S. Geological Survey Water-Resources Investigations Report 96-4040, 46 p.

Southeastern Geological Society, 1986, Hydrogeological units of Florida: Tallahassee, Florida Bureau of Geology Special Publication 28, 9 p.

Southwest Florida Water Management District, 1996, Northern Tampa Bay Water Resources Assessment Project: Vol. 1, Surface-water/ground-water interrelationships: Brooksville, $427 \mathrm{p}$.

Southwest Florida Water Management District, 2007, Minimum flows and levels: South Florida Water Management District database, accessed February 21, 2008, at: http:// www.swfwmd.state.fl.us/about/isspapers/mfl.html.

Southwest Florida Water Management District, 2008, Rainfall data summaries: South Florida Water Management District database, accessed January 8, 2008, at: http://www.swfwmd. state.flus/data/wmdbweb/rainsum.htm.

Steele, T.D., 1968, Digital-computer applications in chemicalquality studies of surface water in a small watershed: International Association of Scientific Hydrology, Publication 80, p. 203-214

Stewart, M., Cimino, J., and Ross, M.A., 2007, Calibration of base flow separation methods with streamflow conductivity: Ground Water, v. 45, no. 1, p. 17-27.
Tihansky, A.B., 2005, Effects of Aquifer Heterogeneity on Ground-Water Flow and Chloride Concentrations in the Upper Floridan Aquifer near and within an Active Pumping Well Field, West-Central Florida: U.S. Geological Survey Scientific Investigations Report 2005-5268, 75 p.

Trommer, J.T., Sacks, L.A., and Kuniansky, Eve, 2007, Hydrology, water quality, and surface- and ground-water interactions in the upper Hillsborough River watershed, west-central Florida: U.S. Geological Survey Scientific Investigations Report 2007-5121, 71 p.

Uhlenbrook, S., Frey, M., Leibundgut, C., and Maloszewski, P., 2002, Hydrograph separations in a mesoscale mountainous basin at event and seasonal timescales: Water Resources Research, v. 38, no. 6, p. 31-1 to 31-14.

U.S. Geological Survey, variously dated, National field manual for the collection of water-quality data: U.S. Geological Survey Techniques of Water-Resources Investigations, book 9, chaps. A1-A9, 2 v., variously paged [Chapters were published from 1997-1999; updates and revisions are ongoing and available at: http://water.usgs.gov/usgs/owq/QAfolder/ Errata.html.

U.S. Geological Survey, 1999, Strategic directions for the Water Resources Division, 1998-2008: U.S. Geological Survey Open-File Report 99-249, 19 p.

Wahl, K.L., and Wahl, T.L., 1988, Effects of regional groundwater level declines on stream flow in the Oklahoma Panhandle, in Proceedings of the symposium on water-use data for water resource management: Tucson, American Water Resources Association, p. 239-249.

Wels, C., Cornett, R.J., and Lazerte, B.D., 1991, Hydrograph separation: A comparison of geochemical and isotopic tracers: Journal of Hydrology, v. 122, no. 4, p. 253-274.

Winter, T.C., Harvey, J.W., Franke, O.L., and Alley, W.M., 1998, Ground water and surface water-A single resource: U.S. Geological Survey Circular 1139, 79 p.

Wolansky, R.M., and Thompson, T.H., 1987, Relation between ground water and surface water in the Hillsborough River basin, west-central Florida: U.S. Geological Survey WaterResources Investigation Report 87-4010, 58 p.

Wright, C.E., 1970, Catchment characteristics influencing low flows: Water and Water Engineering, v. 74, p. 468-471. 

